\title{
Az epidemiológiai surveillance és járványmatematikai előrejelzések szerepe a pandémiás hullámok megelőzésében, mérséklésében - hol tartunk most, és hová kellene eljutni
}

\author{
Oroszi Beatrix ${ }^{1}$, Horváth J. Krisztina ${ }^{1}$, \\ Túri Gergó ${ }^{1 *}$, Krisztalovics Katalin ${ }^{1}$, Röst Gergely ${ }^{2}$ \\ ${ }^{1}$ Semmelweis Egyetem, Epidemiológiai és Surveillance Központ, Budapest, Magyarország \\ ${ }^{2}$ Szegedi Tudományegyetem, Bolyai Intézet, Szeged, Magyarország \\ Beérkezett: 2021. 05. 11.; Elfogadva: 2021. 05. 25.
}

\begin{abstract}
Összefoglaló
A Járványmatematikai és Epidemiológiai Projekt egy egyedülálló kezdeményezés Magyarországon, mely jelentős tudást és tapasztalatot halmozott fel a COVID-19 világjárvány során. Jelen tanulmány a pandémia 2 . hullámának példáján keresztül áttekinti, hogy miként múködött a járványügyi észlelés és monitorozás rendszere, hogyan, milyen eredményekkel végezték a projekt munkatársai a helyzet- és kockázatértékelést, az előrejelzések készítését, végül javaslatokat fogalmaz meg a surveillance- és előrejelző rendszer fejlesztésére a járványügyi biztonság növelése érdekében.

A 2. járványhullám 2020. június 22. és 2021. január 24. között zajlott Magyarországon, melynek során a megerősített COVID-19 esetek száma 356197 fó volt, ami az első hullámban regisztrált esetszám 87-szerese. Összesen 12226 megerősített COVID-19 halálesetet regisztráltak, az első hullámban jelentett szám 21 -szeresét. Az országos R érték először 2020 augusztusában emelkedett 1,0 fölé. Mintegy 3 héttel azután, hogy az R érték augusztus utolsó hetében tartósan 1,0 fölé emelkedett, a halálos kimenetelű COVID-19 esetszámok növekedése is elindult, mivel a fiatalokról a járvány az idősebb korosztályokra is átterjedt. Mindezt a matematikai modellezési eredmények hetekkel korábban jelezték.

November elején az előrejelzés 12000 fó feletti kórházi ápoltat vetített előre a karácsonyi időszakra, melynek elkerülésére kormányzati intézkedéscsomag készült. A 2020. november 1 l-i szigorítás a járványt az eredeti pályáról eltérítette, így a kórházban kezeltek száma a 2. hullámban az előrejelzésnek megfelelően 8018 fónél elérte a csúcsot, majd csökkenni kezdett. Január elején a modellezés azt mutatta, hogy a lecsengő szakaszban, az akkori intézkedések mellett is képes az időközben hazánkban is megjelent új variáns, a gyorsabban terjedő SARS-CoV-2 B.1.1.7, járványügyi fordulatot hozni, ami szintén megvalósult.

Összességében az epidemiológiai helyzetértékelés és matematikai modellezés képes volt a második hullám minden fó aspektusát időben és jól megragadni, a veszélyes folyamatokat előre jelezni és ezzel lehetőséget adni a gyors reagálásra. A 2. hullám tapasztalatai megmutatták, hogy a járványmatematikai és epidemiológiai képességek milyen hozzáadott értékkel bírnak a döntéstámogatásban. Az észlelési és előrejelzési rendszereink megerősítése és a matematikai modellezéssel egységes keretrendszerben történő továbbfejlesztése további lehetőségeket nyithat meg az észlelés, megelőzés, egészségügyi és gazdasági károk elhárítása érdekében szükséges döntési folyamatok bizonyítékalapú támogatásában, és az ország járványügyi biztonságának növelésében.
\end{abstract}

Kulcsszavak: COVID-19, pandémia, egészségbiztonság, epidemiológia, surveillance, matematikai modellezés, evidenciákkal támogatott döntéshozatal 


\title{
The role of epidemiological surveillance and mathematical forecasting in preventing and mitigating pandemic waves - what has been accomplished and what should be achieved
}

\author{
Beatrix Oroszi ${ }^{1}$, Krisztina J. Horváth ${ }^{1}$, Gergő Túri ${ }^{1}$, Katalin Krisztalovics ${ }^{1}$, Gergely Röst ${ }^{2}$ \\ ${ }^{1}$ Semmelweis University, Epidemiology and Surveillance Centre, Budapest, Hungary \\ ${ }^{2}$ University of Szeged, Bolyai Institute, Szeged, Hungary
}

\begin{abstract}
Summary
The Mathematical Modelling and Epidemiology Task Force is a unique initiative in Hungary that has accumulated significant knowledge and experience during the COVID-19 pandemic. Using the example of the second wave of the pandemic, the present study reviews how the epidemiological surveillance and monitoring system operated, how the task force carried out the situation and risk assessments as well as forecasting, and finally, makes suggestions for improving the surveillance and forecasting system to increase health security.

The second wave of the pandemic lasted between 22 June 2020 and 24 January 2021 in Hungary. The number of confirmed COVID-19 cases was 356,197, 87 times the number of cases registered in the first wave. A total of 12,226 confirmed COVID-19 deaths were recorded, 21 times the number reported in the first wave. The reproduction number first exceeded 1.0 shortly in early August 2020. About three weeks after the R-value remained consistently above 1.0 in the last week of August, the number of fatal COVID-19 cases started to increase as the epidemic spread from the young to the older age groups. All of this was predicted by mathematical modelling results weeks earlier.

In early November, the forecast projected more than 12,000 hospitalized patients for the Christmas period, so the government introduced new measures to prevent this surge. The restrictions, implemented on 11 November 2020, diverted the epidemic from its original trajectory, so the number of hospital admissions in the second wave peaked at 8,018, as projected, and then began to decline. In January, SARS-CoV-2 B.1.1.7 was detected in Hungary. Modelling showed in early January, that even in the declining phase, and with the measures being in place, this new variant was able to change the epidemiological trend. This was in fact observed on 24 January, when the epidemic curve started to increase again.

Overall, epidemiological situation assessment and mathematical modelling were able to capture all significant aspects of the second wave in a timely manner and precisely, predicting the possible dangerous changes in the situation, and thus providing opportunity for rapid response. The experience of the second wave has shown the added value of integrating comprehensive epidemiological analysis and mathematical modelling into decision making. Strengthening our epidemiological intelligence and forecasting systems, and further enhancing them in a unified framework can open up further opportunities to provide evidence-based support for decision-making processes.
\end{abstract}

Keywords: COVID-19, pandemic, health security, epidemiology, surveillance, mathematical modelling, evidence informed decision making

\section{Háttér}

A koronavírus világjárvány minden bizonnyal a ma éló generációk eddigi legnagyobb járványügyi veszélyhelyzete, mely jelentősen megingatta az elmúlt évtizedek csaknem zavartalan egészségbiztonságát Magyarországon. Az Egészségügyi Világszervezet 2020. március 11 -én deklarálta a COVID-19 terjedését világjárványnak, azóta 2021. április 30-ig mintegy 150 millió megerősített COVID-19 megbetegedést és 3,15 millió halálesetet regisztráltak a világon SARS-CoV-2 fertőzéssel összefüggésben (URL 1). Magyarországon az első megerósített COVID-19 esetet 2020. március 4-én regisztrálták, ezt követően az első hullámot gyorsan meghozott, szigorú központi korlátozó intézkedésekkel elfojtották. Az első hazai hullám során, 2020. június 21 -ig összesen 4102 megerősített esetet azonosítottak, akik közül 573 fö elhunyt.

A világjárványok jellemzője, hogy azokat egy olyan új kórokozó képes elóidézni, amivel még nem találkozott az emberiség, és ezért arra mindenki fogékony. Az új kórokozó addig terjed, míg talál fogékony szervezetet. Kezdetben gyorsan, hullámokban terjed, mert nagyon sok a fogékony személy. A pandémiák általában több járványhullámból álló, hosszú ideig tartó krízist idéznek eló, amelyek nemcsak az emberek testi és lelki jóllétét fenyegetik, hanem zavarokat okoznak a gazdaság és a társadalom múködésében is. Alapvetően két tényezőtől függ, hogy egy újonnan megjelenő, pandémiás potenciállal rendelkező kórokozó milyen súlyos következményeket képes okozni: milyen gyorsan tud terjedni, és mennyire súlyos megbetegedést képes kiváltani. Egy új kórokozó esetén azonban ez a két tényező kezdetben nem ismert, de még később is változhat, ahogy ezt a SARS-CoV-2 világjárvány során is tapasztalhattuk. Az epidemiológia és a járványmatematikai modellezés szisztematikus, tudományos módszertani keretet biztosít ezen kulcsfontosságú paraméterek megismeréséhez és monitorozásához. 
A járványok megelőzésének, előrejelzésének, regisztrálásának, az arra való felkészülésnek és az ellenintézkedéseknek a folyamata - a járványmenedzsment - azt célozza, hogy a járványok egészségügyi és gazdasági hatása a lehető legkisebb legyen. Az epidemiológia és a matematikai modellezés fontos célja a világjárvány kapcsán, hogy a pandémiás kórokozó viselkedését az emberi társadalomban a lehető legpontosabban jellemezze, a kockázatokat és a potenciális egészségkárosodást folyamatosan értékelje, javaslatokat dolgozzon ki kockázatarányos, célzott megelőző és kárenyhítő intézkedésekre, valamint az intézkedések eredményességét ellenőrizze. Az epidemiológia fó munkamódszerei közé tartozik a népegészségügyi surveillance, a járványügyi vizsgálat (a fertőző forrásnak, a kórokozó terjedési módjának és a fertőzés veszélyének kitett személyeknek az azonosítása), az elemző/analitikus vizsgálatok, népegészségügyi intézkedések és programok értékelése, valamint intézkedések kidolgozása az egészséggel kapcsolatos problémák megoldására/kezelésére. Ahhoz, hogy felismerjünk egy járványt, követni tudjuk a természetes alakulását és értékelni tudjuk az ellene tett intézkedések hatásosságát, rendszerezett adatgyứjtésre van szükség. Ezt a rendszerezett adatgyújtést nevezzük surveillance-nak, ez képezi az alapját annak, hogy elegendő információt gyüjtsünk a cselekvéshez. A járványok terjedésének megítéléséhez, az intézkedések megalapozásához nem elegendő egy „begyújtött számadat”, a cselekvéshez szükséges információkat az adott járvány legfontosabb mutatóinak változása, azok iránya, sebessége - dinamikája - szolgáltatja. Matematikai modellekkel pedig feltárhatók a járvány dinamikáját leginkább meghatározó tényezők, valamint előzetesen összehasonlíthatók a tervezett, különböző időzítésű és szigorúságú intézkedések mellett várható járványlefutások.

\section{A Járványmatematikai és Epidemiológiai Projekt megalakulása, felépítése és munkafolyamata}

A COVID-19 járvány magyarországi terjedésének matematikai modellezésére és epidemiológiai elemzésére a miniszterelnök egy szúk körü találkozó után, 2020. március 16-án kérte fel Röst Gergelyt, a munka feltételeinek biztosításával pedig megbízta Palkovics László innovációs és technológiai minisztert. Ezt követően az Innovációs és Technológiai Minisztérium (ITM) napokon belül létrehozta a Járványmatematikai és Epidemiológiai Projektet Röst Gergely vezetésével a COVID-19 pandémia epidemiológiai elemzésére, a terjedés matematikai modellezésére, előrejelzések készítésére, annak érdekében, hogy a döntéshozóknak támogatást nyújtson a bizonyítékokon alapuló döntéshozatalban. A projekt pillérei a szegedi járványmodellező kutatócsoport mellett az Oroszi Beatrix vezette epidemiológiai elemző csoport, és a Szócska Miklós vezette „put data in action” csoport. Ezekhez kapcsolódott még a virtuális Szeged-szimulá- tort készítő ágensalapú modellező csoport, valamint a kontaktus-mintázatok és attitüdök változását kutató matematikai társadalomtudományi csoport, de speciális feladatokban számos egyéb kutató is közremúködött.

A projekt Magyarországon egyedülálló és innovatív kezdeményezés abban a tekintetben, hogy többféle, speciális kompetenciájú szakember munkáját ötvöző multidiszciplináris csapatként páratlan tudáskombinációt volt képes létrehozni, és a járványügyi védekezés szolgálatába állítani.

A járvány első hullámában a munkacsoport napi jelentéseket készített, később az alábbi munkarend alakult ki. Minden hétfőre készült egy rövid járványügyi helyzetértékelés az előző hétrôl, amit az Innovációs és Technológiai Minisztérium gazdasági kamarák bevonásával megtartott egyeztető fórumán ismertettek. Kedden egy nagyon részletes jelentés készült mintegy 100 dia terjedelemben, ami tartalmazta a nemzetközi járványügyi helyzet értékelését, a magyarországi járvány epidemiológiai elemzését, a matematikai modellezési eredményeket, szcenárió-analízeseket, a legújabb tudományos eredmények és a nemzetközi járványügyi szervezetek (az Európai Betegségmegelőzési és Járványvédelmi Központ [ECDC] és az Egészségügyi Világszervezet [WHO]) legfrissebb ajánlásainak összegzését. Ez a jelentés a szerdai kormányülések fontos háttéranyaga lett. Csütörtökönként az ITM-ben a legújabb fejleményeket ismertető prezentációk bemutatása és adategyeztető megbeszélés („briefing”) zajlott, ahova online konferencia formájában számos állami felsővezető csatlakozhatott. Emellett eseti felkérések szerint készültek stratégiai anyagok és elemzések, továbbá szakmai háttéranyagok miniszterelnöki, illetve nemzetközi találkozókra, egyéb fórumokra. Ilyen fórum volt például a legsúlyosabb járványhelyzet idején a kórházigazgatók tájékoztatása, amelynek egyik anyagát szintén ez a munkacsoport készítette. Az ITM felkérésére 2020 augusztusában készült el angol és magyar nyelven a Vállalati Fehér Könyv (Bognár et al. 2020), amely a gazdálkodó szervezetek számára gyakorlati útmutatóként szolgált a 2. járványhullámra való felkészüléshez. A munkacsoport a tudományos eredményeit, módszertani fejlesztéseit rendszeresen rangos nemzetközi folyóiratokban publikálja (Barbarossa et al. 2021; Bartha et al. 2020; Boldog et al. 2020; Karsai et al. 2021; Koltai et al. 2021; Péni et al. 2020; Reguly et al. 2021; Röst et al. 2020; Szócska et al. 2021).

Jelen tanulmány nem vállalkozik az összes releváns epidemiológiai funkció bemutatására. Fókusza a magyarországi COVID-19 pandémia 2. hullámának példáján keresztül bemutatni, hogy miként múködött az észlelés és monitorozás rendszere a fertőzőbeteg-jelentő rendszer keretei között Magyarországon, hogyan, milyen eredményekkel végezték a projekt munkatársai a helyzetés kockázatértékelést, valamint az előrejelzések készítését és a szcenárió-elemzést, végül javaslatokat fogalmaz meg a járványügyi surveillance- és előrejelző rendszer fejlesztésére a járványügyi biztonság növelése érdekében. 


\section{Alkalmazott módszerek}

Azoknak az intézkedéseknek, amik az emberek napi tevékenységét befolyásolják vagy korlátozzák, miközben a járványvédekezést szolgálják, arányosnak kell lennie a kockázat nagyságával, és azokkal az előnyökkel, amiket az intézkedéstől bizonyítottan várni lehet. A járvány jövőbeni alakulásáról, a lehetséges szcenáriókról sem lehet érdemit mondani anélkül, hogy az aktuális helyzetet nem ismernénk pontosan. A járványügyi kockázatértékelés tehát mindennek az alapja, ez pedig minden esetben leíró epidemiológiával kezdődik. Az epidemiológiai helyzetértékeléshez szükséges adatok többsége a jelenleg rendelkezésre álló surveillance-rendszerekből származik.

Magyarországon a jelentendő fertőző betegségek nyilvántartását és így a COVID-19 magyarországi járványügyi helyzetére vonatkozó adatgyújtést (klinikai és laboratóriumi alapadatok) a Nemzeti Népegészségügyi Központ (NNK) végzi az általa múködtetett Országos Szakmai Információs Rendszer (OSZIR) segítségével (URL 2). A COVID-19 fertőző betegségre vonatkozó jelentési rendet és a jelentés alapjául szolgáló esetdefiníciót (kit tekintünk a világjárványban regisztrált esetnek) az NNK által kiadott eljárásrend tartalmazza, mely nemzetközi ajánlásokon alapul. Az először 2020. januárban kiadott eljárásrendet az NNK több alkalommal frissítette, miután ECDC és a WHO felülvizsgálta surveillanceprotokolljait (URL 3). A 2020. június 11-i magyar eljárásrend alapján megerősített COVID-19 esetnek minősül minden olyan személy, akinél a SARS-CoV-2 nukleinsavának kimutatásával igazolták az új koronavírus által okozott fertőzést, függetlenül a klinikai tünetek fennállásától (tehát a tünetmentesen fertőzött személy is eset). A COVID-19 betegséggel összefüggő haláleset meghatározását az NNK hatályos eljárásrendje nem tartalmazza.

A 2020. november 7-i eljárásrend annyiban módosított az esetdefiníción, hogy a megerósített eset laboratóriumi igazolása a SARS-CoV-2 antigénjének (az immunrendszer számára felismerhető, jellemző alkotóelemének) kimutatásával is elfogadhatóvá vált. Az eljárásrend alapján a COVID-19 gyanús eseteket (akiknek a tüneteik és a lehetséges fertőződés körülményei megfelelnek a klinikai és epidemiológiai kritériumoknak, vagy akiknél az orvos úgy dönt) a betegellátónak (háziorvosnak vagy járó-/fekvóbeteg-ellátónak) jelentenie kell az OSZIR-ba (URL 4). Az OSZIR-ba bejelentett adatokat a megyei/ fóvárosi kormányhivatalok járási/kerületi hivatalainak népegészségügyi feladatkörben eljáró munkatársai a járványügyi vizsgálat alapján kiegészítik, karbantartják. Ezenkívül az egészségügyi szolgáltatók a közösségi vagy intézményi, illetve az egészségügyi ellátással összefüggő járványok gyanúját is jelenteni kötelesek az OSZIR-ba. A fekvőbeteg-ellátó intézmények részére kiegészítő, esetalapú, Excel-táblában történő napi adatgyújtést is elóírt az NNK.
A fertőző beteg bejelentéséből származó klinikai adatokat egészíti ki az NNK laboratóriumi adatgyújtése. Jogszabályi kötelezettség alapján a SARS-CoV-2 kimutatását végzố laboratóriumok a COVID-19 vizsgálati eredményeket napi rendszerességgel automatikusan, interfészen küldik az OSZIR mikrobiológiai alrendszerébe (URL 5). A publikusan közölt, megerősített COVID-19 esetek és halálesetek, valamint az elvégzett laboratóriumi vizsgálatok számára vonatkozó adatok az NNK fent részletezett adatgyújtéseinek összesítéséből származnak. Ezek ismeretében rajzolható fel a járványgörbe, melyen az egységnyi idő (pl. egy nap) alatt kezdődött/regisztrált új megbetegedések száma követhető. Egy megbízható, valid adatokon alapuló járványgörbe lefutása (meredeksége, kitérésének mértéke stb.) képes jellemezni a legszemléletesebben a járvány dinamikáját.

A már meglévő fertózőbeteg-jelentő rendszeren alapuló surveillance önmagában nem volt képes a pandémia során megnövekedett információigényt kielégíteni, ezért a Járványmatematikai és epidemiológiai projektnek további adat- és információforrásokat is igénybe kellett venni a minél teljesebb epidemiológiai helyzetértékeléshez. Összességében a projekt döntően a jogszabály szerinti adatgyúijtésekre kijelölt intézmények adatait dolgozta fel meghatározott indikátorok szerint, mely alól kivételt képez az elsősorban a kontaktusszámok alakulását monitorozó online kérdőív, a MASZK (1. számú táblázat).

A reprodukciós szám $(\mathrm{R})$ az egyik legfontosabb indikátor. Az alap reprodukciós szám $\left(\mathrm{R}_{0}\right)$ azt mutatja meg, hogy egy fertőzött személy közvetlenül hány további embert fertőz meg a fertőzőképessége teljes időtartama alatt egy teljesen fogékony populációba bekerülve. Ez fejezi ki a járvány teljes terjedési potenciálját. Amikor a fogékonyak száma csökken egy populációban (egyre többen védettséget szereznek a betegség ellen), illetve az emberek elkezdenek egyéni szinten védekezni a fertőzés ellen (pl. távolságtartással, maszkhasználattal, kontaktusszám-csökkentéssel), és hatékony járványügyi intézkedések történnek a fertőző személyek azonosítására és elkülönítésére, valamint a közeli kontaktok karanténba helyezésére, akkor a reprodukciós szám (R) csökken. A reprodukciós szám tehát idővel változik, attól függő" en, hogy a járvány terjedése éppen gyorsul $(\mathrm{R}>\mathrm{l})$, lassul $(\mathrm{R}<\mathrm{l})$, vagy elérte a csúcsát, illetve stabilizálódik $(\mathrm{R} \approx \mathrm{l})$. Ezt nevezzük effektív reprodukciós számnak, aktuális értéke pedig hasznos információ nemcsak a helyzetértékeléshez, de az előrejelzések készítéséhez és a szcenárióelemzéshez is, mivel ez jellemzi leginkább a járvány terjedési ütemét egy adott intézkedési, védekezési szint mellett. Az effektív reprodukciós szám egy származtatott mutató, a surveillance-adatokból matematikai-statisztikai módszerekkel becsülhető. A módszertan nemzetközi standardokon alapul, és a Röst et al. 2020 publikációban is megtalálható. 
1. táblázat $\mid$ Az országos szintű epidemiológiai helyzetértékeléshez felhasznált legfontosabb indikátorok, alcsoportbontások, valamint a felhasznált adatok típusa és forrása a 2. járványhullám során (n. a. = nem áll rendelkezésre adat), Magyarország, 2020-2021

\begin{tabular}{|c|c|c|c|c|}
\hline & Példák mutatókra & Alcsoportbontások & Adatok típusa & Elsődleges adatok forrása \\
\hline $\begin{array}{l}\text { Terjedés } \\
\text { vizsgálata }\end{array}$ & $\begin{array}{l}\text { Megerősített COVID-19 esetek napi } \\
\text { száma, } 7 \text { napos mozgóátlaga, aránya } \\
100000 \text { lakosra, } 14 \text { napos kumulatív } \\
\text { incidencia* } 7 \text { és } 14 \text { napos növekedési } \\
\text { arány, R érték* }\end{array}$ & $\begin{array}{l}\text { Kor, nem, földrajzi } \\
\text { terület }\end{array}$ & $\begin{array}{l}\text { Egyedi adatok személy- } \\
\text { azonosításra alkalmatlan } \\
\text { módon }\end{array}$ & $\begin{array}{l}\text { Nemzeti Népegészségügyi } \\
\text { Központ (NNK) }\end{array}$ \\
\hline Tesztelés & $\begin{array}{l}\text { Napi elvégzett tesztek száma, pozitív } \\
\text { tesztek aránya, egy megerősített esetre } \\
\text { jutó tesztek száma }\end{array}$ & N. a. & Országos szinten aggregált & koronavírus.gov.hu \\
\hline $\begin{array}{l}\text { Társadalmi } \\
\text { kapcsolatok, } \\
\text { viselkedés }\end{array}$ & $\begin{array}{l}\text { Korcsoportok közötti napi kontaktusok } \\
\text { száma, maszkviselési hajlandóság, belföldi } \\
\text { és külföldi utazások, otthon töltött idő, } \\
\text { vakcinák iránti attitűdök }\end{array}$ & $\begin{array}{l}\text { Kor, nem, lakhely, } \\
\text { iskolai végzettség, } \\
\text { háztartás mérete }\end{array}$ & $\begin{array}{l}\text { Önkéntesen szolgáltatott } \\
\text { egyedi adatok személy- } \\
\text { azonosításra alkalmatlan } \\
\text { módon }\end{array}$ & $\begin{array}{l}\text { Magyar Adatszolgáltató } \\
\text { Kérdőív (MASZK), } \\
\text { havi rendszerességú } \\
\text { reprezentatív közvéle- } \\
\text { mény-kutatások }\end{array}$ \\
\hline Kórházi ellátás & $\begin{array}{l}\text { Adott napon kórházi kezelésben részesülő } \\
\text { COVID-19 betegek száma, súlyos } \\
\text { állapotú és lélegeztetett betegek száma, } \\
\text { aránya, növekedési üteme }\end{array}$ & Földrajzi terület & $\begin{array}{l}\text { Aggregált, prevalencia* } \\
\text { típusú adat }\end{array}$ & $\begin{array}{l}\text { Elektronikus Egészségügyi } \\
\text { Szolgáltatási Tér (EESZT) }\end{array}$ \\
\hline COVID-19 halál & $\begin{array}{l}\text { COVID-19-cel összefüggésben elhunytak } \\
\text { száma, aránya } 100000 \text { lakosra, letalitás* }\end{array}$ & $\begin{array}{l}\text { Kor, nem, földrajzi } \\
\text { terület }\end{array}$ & $\begin{array}{l}\text { Egyedi adatok személy- } \\
\text { azonosításra alkalmatlan } \\
\text { módon }\end{array}$ & $\begin{array}{l}\text { Nemzeti Népegészségügyi } \\
\text { Központ }\end{array}$ \\
\hline Összes halál & $\begin{array}{l}\text { Összes elhunyt száma, aránya } 100000 \\
\text { lakosra, többlethalálozás* }\end{array}$ & $\begin{array}{l}\text { Kor, nem, földrajzi } \\
\text { terület }\end{array}$ & $\begin{array}{l}\text { Egyedi adatok személy- } \\
\text { azonosításra alkalmatlan } \\
\text { módon }\end{array}$ & $\begin{array}{l}\text { Elektronikus Anyakönyvi } \\
\text { Rendszer, Központi } \\
\text { Statisztikai Hivatal }\end{array}$ \\
\hline
\end{tabular}

*Megjegyzés: kumulatív incidencia: adott időszakban regisztrált összes új megbetegedés gyakorisága; prevalencia: adott időpontban/időszakban észlelt összes (még fennálló+új) megbetegedés gyakorisága; R érték: reprodukciós szám; letalitás: 100 betegből meghaltak aránya (\%), többlethalálozás: a korábbi évek adatai alapján várt értéket meghaladó halálesetek száma

Forrás: saját szerkesztés

\section{A 2. járványhullám leíró epidemiológiája és modellezési eredmények}

A 2. járványhullám első, valamint utolsó napjának e járványhullám csúcsát közvetlenül megelőző, illetve követő hullámvölgy mélypontjának napját tekintettük, amikor a legalacsonyabb napi esetszámot regisztrálták. Eszerint a 2. járványhullám 2020. június 22. és 2021. január 24 . (2020. 26. hete és 2021. 3. naptári hete) között zajlott Magyarországon. Népegészségügyi jelentőségét az adja, hogy az első hullámnál jóval nagyobbnak bizonyult: a laboratóriumi vizsgálattal megerősített COVID-19 esetek száma 356197 fó volt (100 000 lakosra vonatkoztatva: 3592 fó, a 2021. április 13.7 órai állapotnak megfelelően), mely az első járványhullámban regisztrált esetszám 87-szerese. Az országos R érték átmeneti 1,0 fölé emelkedését 2020 augusztusának első két hetében észleltük először egy Veszprém megyei halmozódás kapcsán, mely már a második hullám fenyegető gyorsulásának előjele volt. 2020. augusztus 26 . körül ismét 1,0 fölé emelkedett az $\mathrm{R}$ érték, majd szeptember elején rövid időre 2,0 fölé, ami az importált esetek nélkül is fennállt. A napi átlagos esetszám a 34 . heti 35 -ről két hét alatt 400 fölé, azaz mintegy 12 -szeresére ugrott, ami a lakosság széles körében észlelhetô gyors közösségi terjedés beindulását jelezte. A korspecifikus megbetegedési ará- nyok (a korcsoportba eső 100000 lakos közül megbetegedettek száma) alapján megállapítható volt, hogy a járvány akkor még elsősorban a fiatal felnőtt korcsoportokat érintette. A fiatalokról azonban a járvány szeptember folyamán fokozatosan az idősebb korosztályokra is átterjedt.

A teljes 2. járványhullám során regisztrált összes megerősített COVID-19 eset 68,0\%-a (242 058 fó) 25-64 éves, 18,4\%-a (65 577 fó) 65 éves vagy idősebb, 9,3\%-a (33 183 fó) 15-24 éves és 4,3\%-a (15 368 fó) 14 éves vagy fiatalabb volt. A korspecifikus megbetegedési arány (100 000 lakosra) a 80 éves és idősebbek között volt a legmagasabb (5490 fó), őket követte a 40-49 évesek (4863 fó), az 50-64 évesek (4314 fö), a 30-39 évesek (3943 fó), a 20-29 évesek (3903 fó) érintettsége. A korspecifikus megbetegedési arány (100 000 lakosra) a 6579 évesek körében 2817 fö, a 10-19 éveseknél 2446 fö és a 9 éves vagy fiatalabbaknál 561 fó volt.

Mintegy 3 héttel az után, hogy az R-érték augusztus utolsó hetében tartósan 1,0 fölé emelkedett, a regisztrált halálos kimenetelű COVID-19 esetszámok növekedése is elindult. A 2. járványhullám során összesen 12226 megerősített COVID-19 eset halálát jelentették, ami az első hullámban regisztrált halálesetek számának 2l-szerese. Az egy héten regisztrált esetszám 2020. 35. hétig 1000 fó alatt maradt, a 36-42. héten 1000 fölé emelke- 
dett, de nem lépte túl a 10000 fót, majd 2020. 43. hete és 2021. 1. hete között 10000 fó feletti volt. A 2020. évi 48. naptári héten volt a legmagasabb az egy hét alatt regisztrált esetszám (39 166 fó), ami azt követően a 2. járványhullám végéig csökkent.

A 2. járványhullámban regisztrált 356197 fó közül 12945 esetben a megbetegedés halállal végződött, a nyers letalitás (100 megerósített COVID-19 esetre vonatkoztatva) 3,6\% volt országosan. Az elhunytak 83,9\%-a (10 862 fó) 65 éves vagy idősebb, 16,0\%-a (2072 fö) 25-64 éves és 11 fó $(0,1 \%)$ 15-24 éves. A nyers letalitás a 80 éves vagy idősebbek között volt a legmagasabb (23,4\%), őket követte a 65-79 éveseké $(12,8 \%)$ és az 50-64 éveseké $(2,1 \%)$. Nem fordult elő haláleset a 18 évesnél fiatalabbak között. A megerősített COVID-19 esetszám (a fertőzés igazolásának dátuma szerint) és a COVID-19 betegséggel összefüggő halálesetek száma (a halálozás dátuma alapján) az 1 ábrán látható.

A SARS-CoV-2-fertőzés terjedésének megelőzésére a 2. járványhullámban kombinált, nem-farmakológiai intézkedések álltak rendelkezésre. Ezek fó pillérei a távolságtartás a közeli kontaktusok számának csökkentése érdekében, az egyéni védekezés (maszkhasználat, kézhigiéné), valamint az esetek járványügyi felderítése és felügyelete, úgymint a betegek izolálása, a kontaktszemélyek karanténba helyezése stb. (URL 6). Ez utóbbihoz megfelelő tesztelési kapacitásra, képzett járványügyi szakemberekre, valamint hatékony és precíz kontaktus- kutatásra van szükség, amely az új fertőzöttek detektálását és lehető leggyorsabb elkülönítését teszi lehetővé. A betegek időben történő elkülönítésével, a tünetmentes fertőzöttek karanténba helyezésével csökkenthető a fertőzés átadási lehetőségének időtartama, ezért ezek a járványügyi intézkedések - ha legalább 80\%-ban megtörténnek - az R érték csökkentésének egyik fontos eszközei. Ha viszont túl későn történik a betegek elkülönítése és a tünetmentes fertőzöttek karanténba helyezése, akkor annak járványügyi eredménye minimális lesz, miközben a társadalomra és gazdaságra rótt teher megnő, mivel feleslegesen vonják ki az embereket a munkából, tanulásból.

Számos, elsősorban társadalmi kontaktuscsökkentésre és egyéni védekezésre irányuló kormányzati intézkedés született, melyek közül járványügyi szempontból az alábbiak voltak a leginkább relevánsak (1. ábra):

$\rightarrow$ 2020. 29. hét: A külföldről történő behurcolás veszélye miatt a kormány meghatározott országok kapcsán beutazási korlátozásokról döntött. Az Operatív Törzs felhívására az országos tisztifóorvos határozatban tette közzé a piros, a sárga és a zöld jelzéssel besorolt országok listáját (URL 7).

$\rightarrow$ 2020. 36. hét: A Kormány a 407/2020. (VIII. 30.) Korm. rendeletben rendelkezik a határellenőrzés 2020. szeptember l-jétól történő ideiglenes visszaállításáról a teljes országhatáron (URL 8).

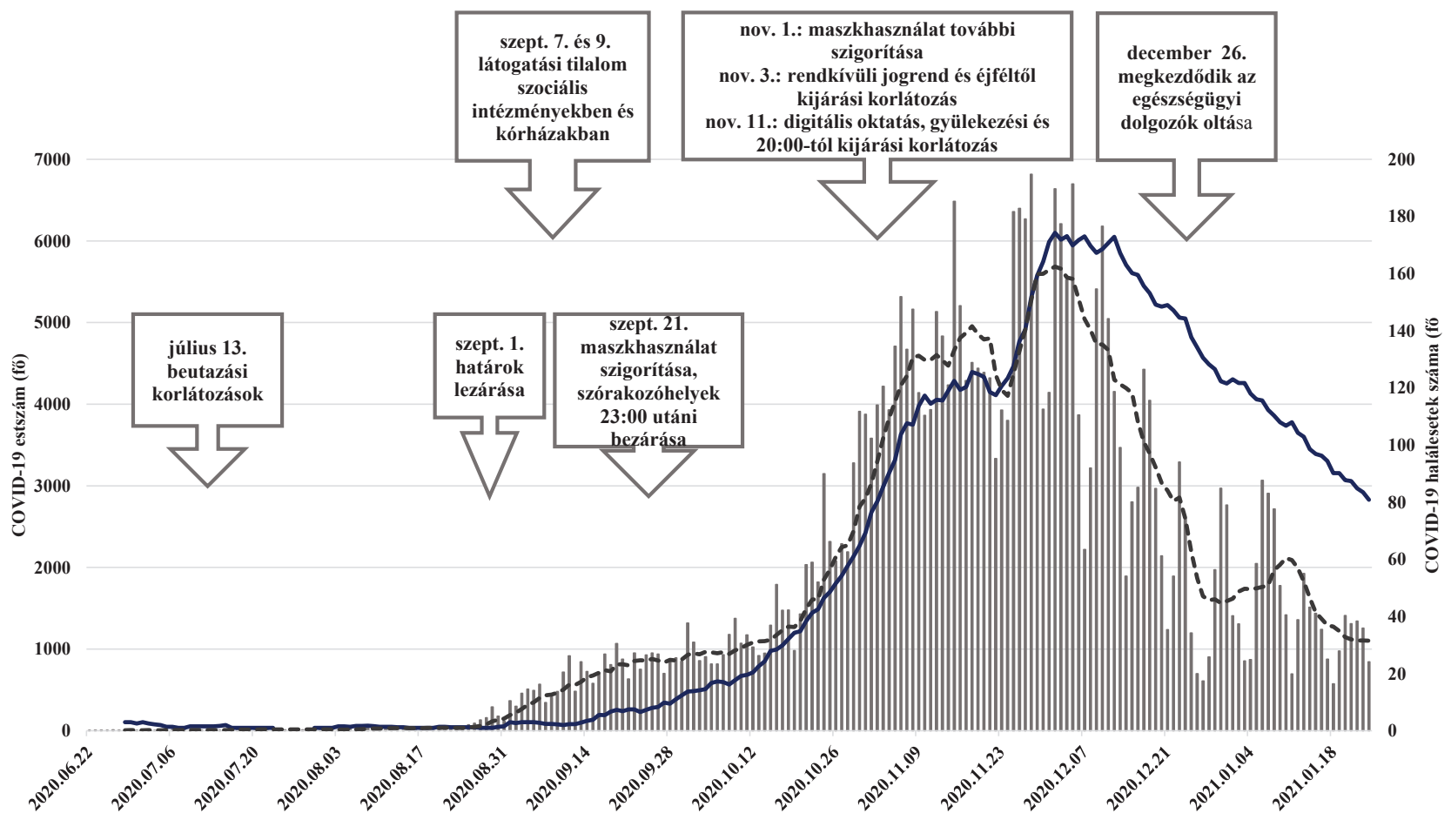

COVID-19 megerősített eset —— halálos kimenetelü COVID-19 esetszám 7 napos mozgóátlaga - - - 7 per. mozg. átl. (COVID-19 megerősített eset) 
$\rightarrow$ 2020. 37. hét: Intézményelhagyási és látogatási tilalom kerül elrendelésre a szociális intézményekben, teljes körü látogatási tilalom a kórházakban (URL 9).

$\rightarrow$ 2020. 39. hét: Kötelező a maszkviselés a bevásárlóközpontokban, mozikban, színházakban, múzeumokban, könyvtárakban, a postai és egyéb ügyfélszolgálatokon, továbbá a tömegközlekedési eszközökön és azok megállóiban, váró helyiségeiben is, valamint a sportlétesítményekben. Az arc eltakarására a sál már nem elegendő, szabályos maszkot kell viselni. A szórakozó- és vendéglátóhelyek 23 óráig lehetnek nyitva. Az 500 fó feletti rendezvények továbbra sem tarthatók meg. A külföldról hazatéróknek 14 napról 10 napra csökken a karantén (URL 10).

$\rightarrow$ 2020. 44. hét: Maszkhasználat további szigorítása: vendéglátóhelyeken és a szórakozóhelyeken is kötelező viselni. A rendőrség sokkal szigorúbban kérheti számon a szabályokat (URL 11).

$\rightarrow$ 2020. 45. hét: A kormány 2020. november 4-től visszaállítja a rendkívüli jogrendet, újra kihirdeti a veszélyhelyzetet, amit az Országgyúlés meghosszabbított. Éjfél és reggel 5 óra között kijárási korlátozást léptet életbe a kormány (URL 12).

$\rightarrow$ 2020. 46. hét: A középiskolákban a 8. évfolyam felett digitális oktatás lép életbe, de a 14 év alattiak számára nyitva maradnak az intézmények (URL 13). Az üzletek 19:00-ig lehetnek nyitva, a kijárási korlátozás 20:00-kor kezdődik. Általános rendezvény és gyülekezési tilalom. A sportmérkőzéseket csak zárt kapuk mellett tarthatják meg. Az éttermek bezár- nak, a szállodák turistákat nem fogadhatnak. Családi összejöveteleken legfeljebb 10 fó találkozhat. A halasztható mútétek felfüggesztésre kerülnek.

$\rightarrow$ 2020.52. hét: 2020. december 27 -én megkezdődött az egészségügyi dolgozók oltása (URL 14).

Az 1000 lakosra jutó elvégzett tesztek száma augusztus végétől szeptember közepéig megduplázódott, majd mintegy 3 hétig stagnált, illetve csökkent. A növekvő járványügyi szükségletek kielégítésére 2020. október 8-tól széles körben elérhetővé váltak az újgenerációs antigén gyorstesztek, melyek egy hónap alatt ismét megduplázták a naponta végzett tesztek számát. Sajnos azonban ez a tesztkapacitás-bóvítés sem tudta már ellensúlyozni a járvány gyorsuló terjedését tükröző pozitív tesztarány növekedést.

A 2. hullám során is folyamatosan zajlott a járvány matematikai modellezése, ebből most négy jellemző fázist ismertetünk, illetve az azokhoz készült számításokból mutatunk be példákat.

\section{A fiatalok között induló járvány átterjedése más korcsoportokra}

Számos nemzetközi példához hasonlóan a 2. hullám kezdetén a vírus terjedése elsősorban a szociálisan aktív fiatalabb korosztályok körében indult el. Amíg a víruscirkuláció főleg ezekben a korcsoportokban történik, addig az esetszámok gyorsan nőhetnek, a kórházban kezeltek száma és a halálozások száma viszont kevéssé változik. Idővel azonban a különböző csoportok közötti kontak-

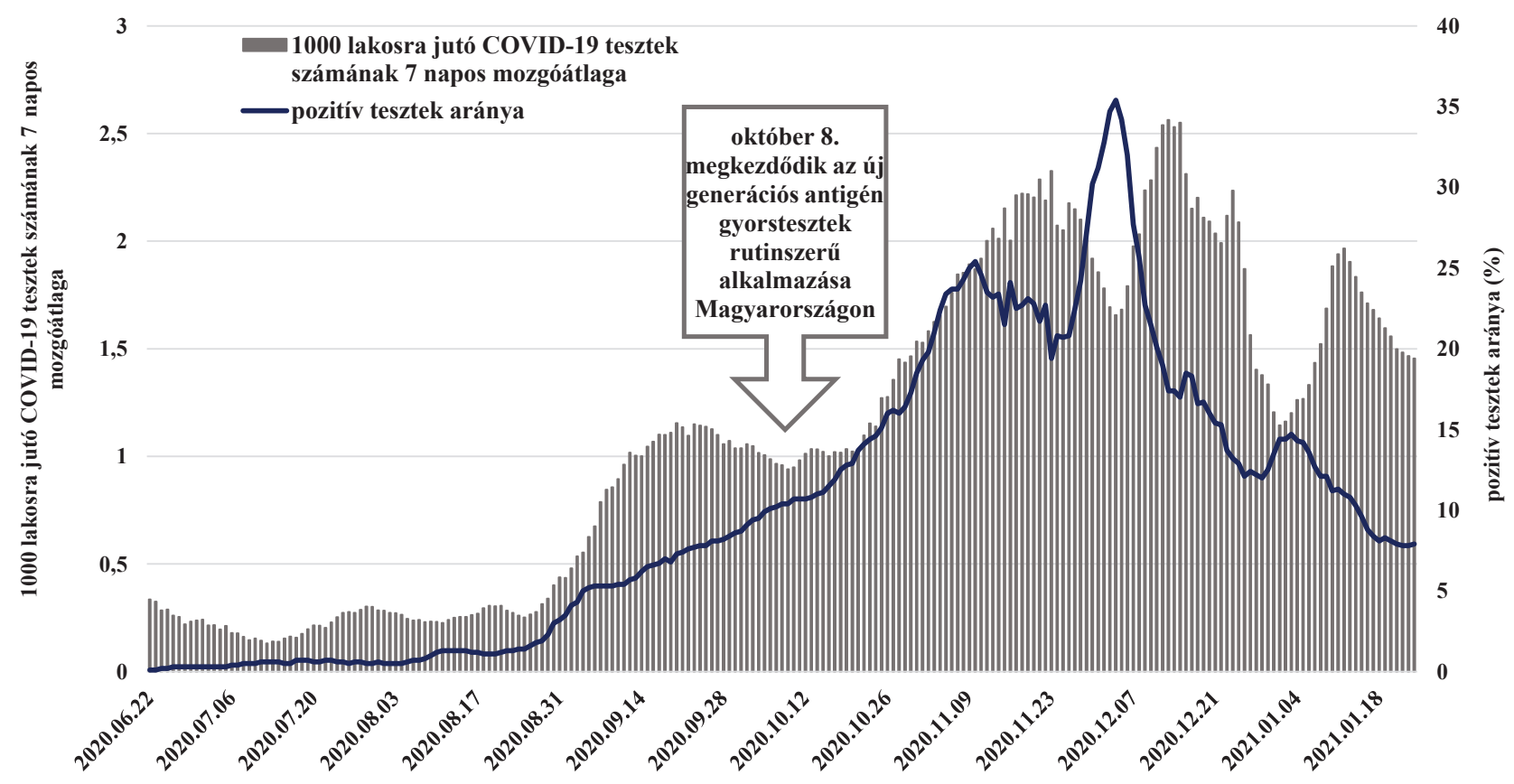

2. ábra

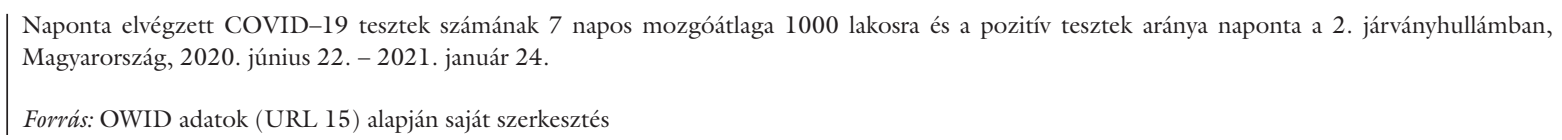


tusok által a fertőzés elkerülhetetlenül eljut a vulnerábilis csoportokhoz is, ami azt eredményezi, hogy a halálozások számának emelkedése néhány hét késéssel követi az esetszámok emelkedését. Erre a jelenségre egy nevezetes példa volt Florida, de több nyugat-európai országban is megfigyelhető volt hasonló jelenség. A folyamat leírására és megértésére az úgynevezett korstrukturált kompartment modellek alkalmasak (lásd Röst et al. 2020), amelyek bemenő paraméterként a korcsoportok közötti találkozások mintázatát leíró kontaktmátrixot is tartalmazzák. A MASZK kutatás pontosan az ilyen kontaktmátrixok empirikus becslése céljából indult (Karsai et al. 2021; Koltai et al. 2021). Egy ilyen modell segítségével készült a 3. ábra, ami előrevetítette a várható esetszámokat az egyes korcsoportokban. Az előrejelzés jó egyezést mutatott a későbbi eseményekkel. A korstrukturált modellünk azt vetítette előre, hogy októberben a halálozások száma is meg fog emelkedni, és ez pontosan így is történt.

\section{Exponenciális felfutó szakasz}

A nyár végi és a szeptember eleji turbulens időszak után újraindult a járvánnyal kapcsolatos kommunikáció is, és a hónap közepére a kontaktusok száma stabilizálódott, az R pedig 1,3-1,4 körüli értékre állt be, ami egy ütemesen gyorsuló járványt jelzett. A tesztelés és a surveillance ugyan ezzel nem tudott lépést tartani, de a halálozási számokból látható, hogy egészen novemberig exponenciális növekedés jellemezte a 2. járványhullámot (4. (a) ábra). Logaritmikus skálán ábrázoltuk a napi COVID-19 halálozások számát, és erre a vizsgált intervallumban jól illeszthető egy egyenes, ami exponenciális növekedést jelent. Ez különösen látványos, ha a halálesetek jelentésének hétközi ingadozását kiszűrő hétnapos mozgóátlagot tekintjük, ami szinte már önmagában is egyenes, és a 2. hullám exponenciális felfutásának markáns jele. Az illesztésből kapott napi növekedési ráta $r=0,06$, ami az $R=\exp \left(r^{*} T\right)$ közelítés szerint (lásd Wallinga-Lipsitch 2007), ahol $T=4,7$ nap a generációs idő (Röst et al. 2020), az $R=1,33$ értéket adja. Ez az $\mathrm{R}$ érték huzamosabb ideig fennállt.

A járvány exponenciális szakaszában könnyú rövid távú előrejelzéseket tenni, hiszen csak egy trendvonallal kell meghosszabbítani a tényadatokat ábrázoló görbét. A nehéz kérdés az, hogy meddig fog tartani ez a fázis és hogyan alakul a járvány a továbbiakban. Az exponenciális felfutásnak vagy az újonnan bevezetett intézkedések, vagy pedig az vet véget, amikor a fogékonyak száma érezhetően csökkenni kezd az átfertőződés miatt. Innentől kezdve a járványdinamika nemlineáris jellege érvényesül, aminek a leírásához komplexebb modellek szükségesek. Érdemes megjegyezni, hogy a 2020 áprilisában készült tanulmányunkban (Röst et al. 2020) a három felvázolt lehetséges 2 . hullám-szcenárió közül a középutas szcenárió az $R=1,32$ értékhez tartozik, és a lefutása nagyon hasonlít a hat hónappal később bekövetkezett 2. hullámhoz.

\section{2020. novemberi intézkedések és a 2. járványbullám csúcsa}

A járványhullám alakulásáról folyamatosan készültek modellezések, a Röst et al. 2020 publikációban közölt metodika (illetve annak módosításai, továbbfejlesztései) alapján. A 4. (b) ábra egy legfelső szintú egyeztetésen bemutatott anyagból lett kiválasztva. A pontozott görbe mutatja a november 5 -én előrejelzett pályát a november 11-i intézkedések nélkül. Ez 12000 fó feletti kórházi ápoltat vetített előre a karácsonyi időszakra. A folytonos

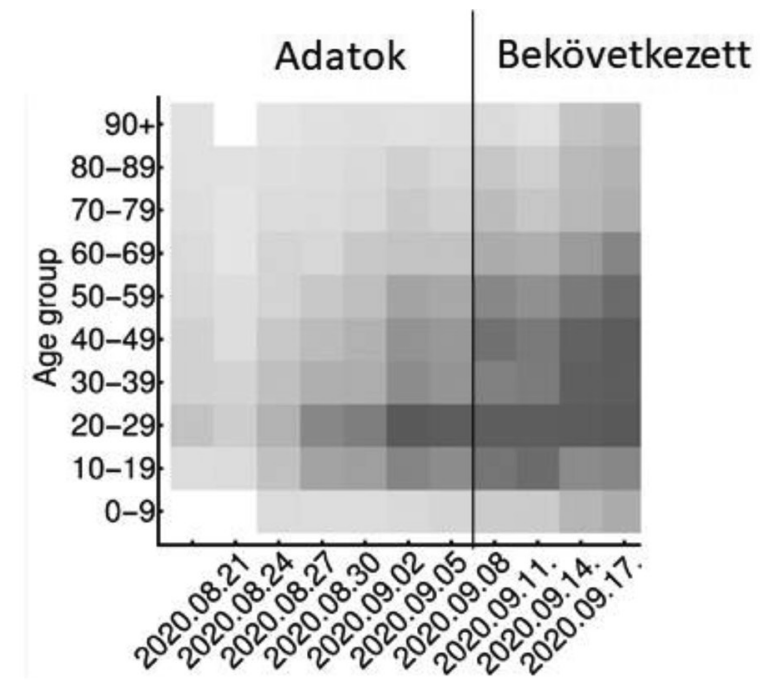

\begin{tabular}{l|l} 
3. ábra & $\begin{array}{l}\text { A COVID-19 korcsoportok közötti terjedésének előrejelzése 2020. szeptember 6-án, Magyaror } \\
- \text { ún. hötérkép) } \\
\text { Forrás: A Járványmatematikai csoport szeptemberi jelentései } \\
(\text { Az előrejelzést és az ábrát készítette Bartha Ferenc, Bogya Norbert, Röst Gergely, Vizi Zsolt) }\end{array}$
\end{tabular}

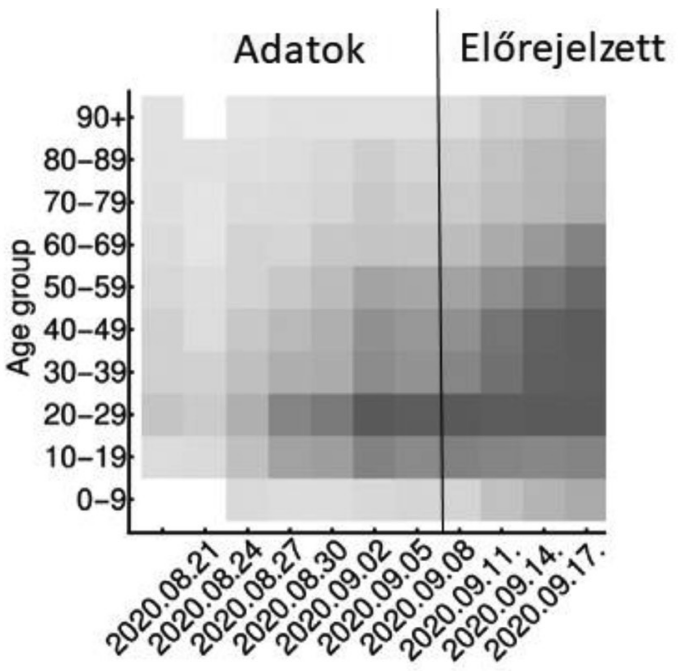


COVID-19 halálesetek a halálozás napja szerint

100

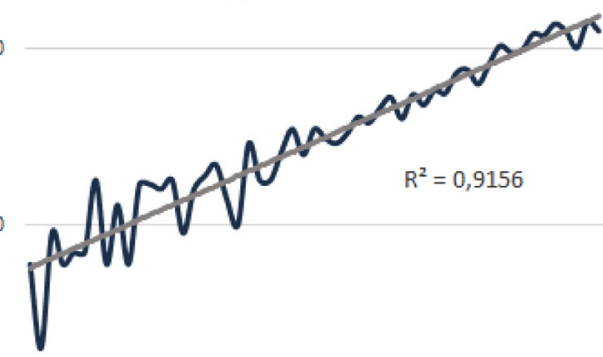

1 व 2 का

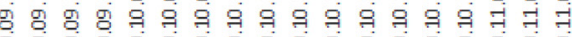

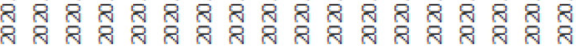

COVID-19 halálesetek hétnapos mozgóátlaga

100

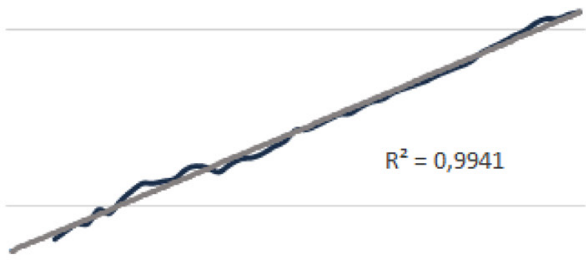

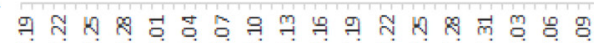

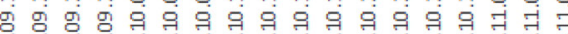

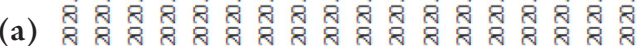

Kórházban ápolt betegek száma

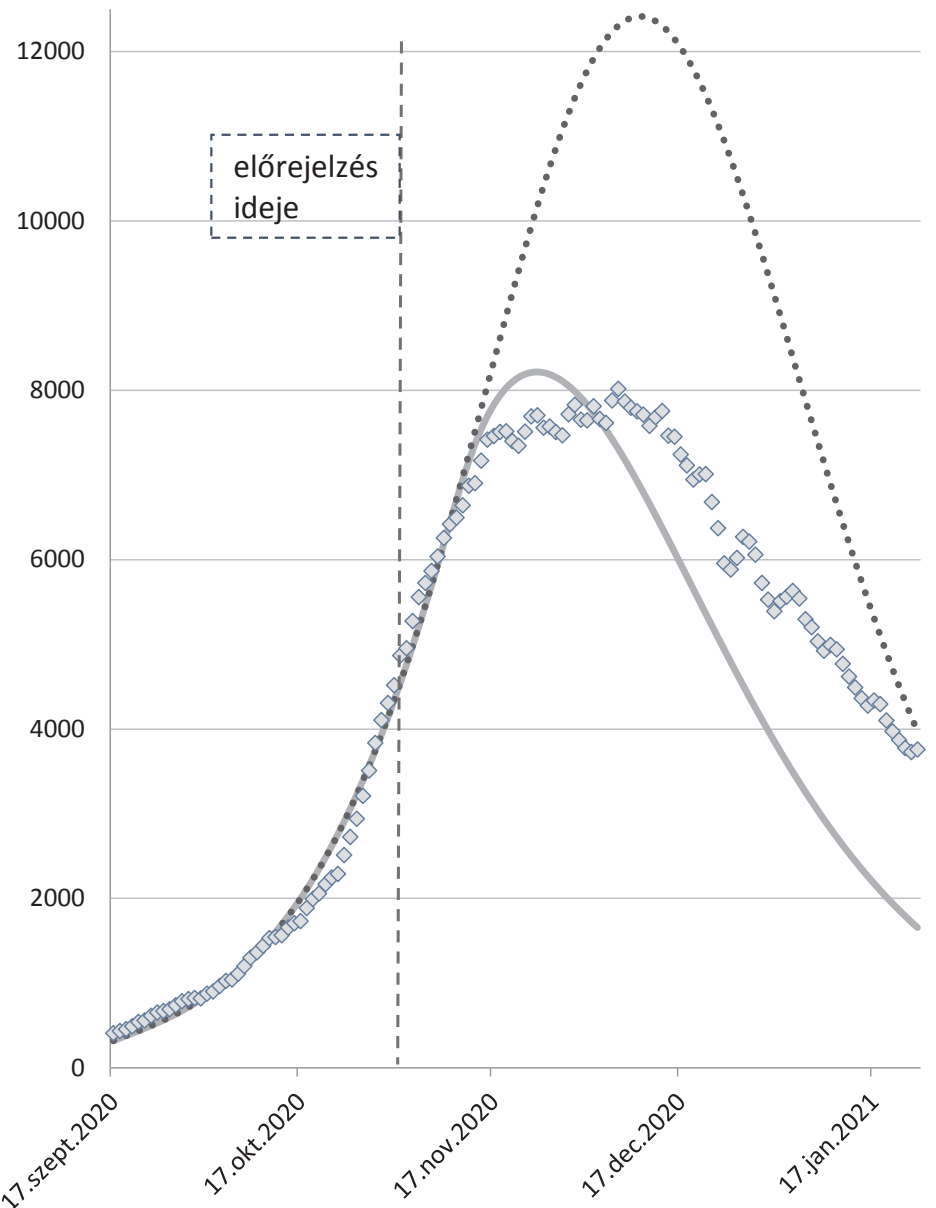

4. ábra

(a) Napi COVID-19 halálozások exponenciális növekedése szeptember közepétôl november közepéig. (b) November elején készült előrejelzés a 2. hullám csúcsának alakulásáról további intézkedések hiányában, illetve 20\%-os kontaktuscsökkentést eredményező novemberi intézkedések esetén, Magyarország, 2020. szeptember - 2021. január

Forrás: (a) NNK adatai alapján saját szerkesztés. (b) Legfelsőbb szintű egyeztetésen 2020. november 7-én bemutatott ábra, kiegészítve a későbbi EESZT tényadatokkal. (Az előrejelzést és az ábrát készítette Bartha Ferenc, Bogya Norbert, Röst Gergely, Vizi Zsolt)

görbe is egy november 5-én készült előrejelzés, amely azt a szcenáriót mutatja, amennyiben az intézkedésekkel 20\%-os kontaktuscsökkentést sikerül elérni. Ez az ábra és a vonatkozó diszkusszió fontos támpont volt a november 11-i, Ausztriához hasonló intézkedéseket foganatosító döntéshez.

A 4. (b) ábrán az előrejelzéseket kiegészítettük a későbbi tényadatokkal, amiket rombuszok jeleznek. A modell nagyon pontosan előre jelezte a következő 2-3 hét számait, valamint a 20\%-os kontaktuscsökkentést feltételező szcenárió pontos egyezést mutatott a későbbi járványcsúcs nagyságával (kevéssel 8000 feletti kórházi ápolt). A limitációkat jelzi, hogy a lecsengő szakaszra már pontatlanabb volt, de az alapvető trendet jó előre jelezte. A limitációk folyamatos újrakalibrálással, illetve a surveillance-adatok pontosságának javításával mérsékelhetőek. Januárban már a B.1.1.7 variáns is terjedni kezdett, ami teljesen új helyzetet teremtett.

\section{Lecsengő fázis és az elsöként az Egyesült Királyságban azonositott ij variáns felbukkanása}

A SARS-CoV-2 B.1.1.7 variáns megjelenése alapjaiban változtatta meg a modellezés keretrendszerét, hiszen ez a variáns egész más paraméterekkel rendelkezik, például a fertőzőképessége 43-90\%-kal nagyobb a vad, vuhani változatnál (Davies et al. 2021). A modellt jelentősen ki kellett egészíteni, hogy követni tudja a két különböző típusú vírusvariáns együttes terjedését. Január elején látható volt, hogy a B.1.1.7 variáns az akkor fennálló intézkedések mellett is képes lehet új hullámot okozni, de ennek időzítése és nagysága akkor még nem volt világos. Az 5. ábrán illusztráljuk az incidencia trendjének lehetséges megváltozását a B.1.1.7 variáns hatására. Az új variánssal kapcsolatos fó bizonytalansági tényezők a variáns epidemiológiai paraméterei (amik elég széles intervallumban mozoghattak) mellett a jövőbeli védekezési 

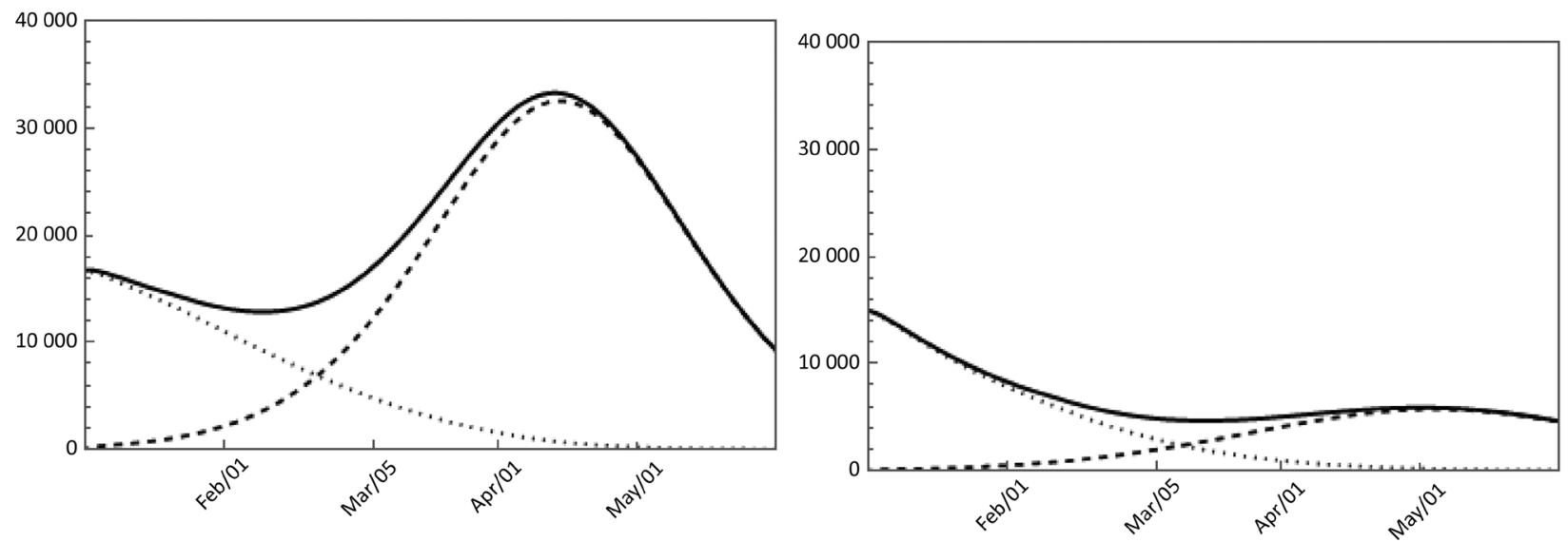

5. ábra

$$
\begin{aligned}
& \text { Sematikus ábrák a brit variáns okozta lehetséges újabb hullámról, Magyarország, 2021. január } \\
& \text { Megjegyzés: a szaggatott görbe az új variáns, a pontozott görbe a régi variánsok által okozott új esetek, a folytonos görbe az előző kettő összege, } \\
& \text { vagyis az összes új eset } \\
& \text { Forrás: A Járványmatematikai csoport január eleji jelentéseiból adaptálva (készítette Bartha Ferenc, Bogya Norbert, Röst Gergely, Vizi Zsolt) }
\end{aligned}
$$

szint, a vakcinálási menetrend alakulása, és leginkább a variáns aktuális elterjedtsége voltak. Ezért javasoltuk már január elején a variánsok elterjedtségének monitorozását többféle módszerrel is (S-gén negativitás PCR-teszteken, illetve szisztematikus génszekvenálás), ami lehetővé tette volna a pontos elörejelzést, ez azonban sajnos nem valósult meg.

\section{A modern surveillance-rendszerekkel kapcsolatos elvárások}

A 2. járványhullám tapasztalatai szerint melyek azok a szempontok, amikre figyelemmel kell lenni az észlelési és előrejelzési rendszereinknek egy következő jelentős járványügyi eseményre történő felkészítésekor?

\section{Egységesség és reprodukálhatóság}

Átfogó COVID-19 epidemiológiai helyzetértékelést jelenleg Magyarországon csak több intézmény adattábláinak felhasználásával lehet végezni. Az értékelést nehezíti, hogy ezek az adatgyưjtések egymással nem harmonizáltak. Érdemes lenne egységes szemlélet szerint továbbfejleszteni és új elemekkel kiegészíteni ezeket a rendszereket, közös surveillance- és monitoring-célokat, továbbá egységes esetdefiníciókat és indikátor-definíciókat meghatározni, a surveillance-folyamatokat dokumentálni és mindenki számára elérhetővé tenni. Pontosan definiálni kellene nemcsak azt, hogy ki számít COVID-19 esetnek, hanem pl. azt is, hogy mi a súlyos lefolyás kritériumrendszere, és ki minősül a COVID-19 betegséggel összefüggő halálesetnek. Az egységes esetdefiníciókat a surveillance-rendszer valamennyi szereplőjének ismerni és alkalmazni kellene annak érdekében, hogy az eredmények ne torzuljanak az eltérôen értelmezett esetdefiníciók miatt. Mindezt oktatási anyagok és tájékoztatók segíthetik elő.

\section{Szenzitivitás és pozitín prediktín érték}

A szenzitivitás a valódi összes eset azon hányadát mutatja meg egy adott célpopulációban, amelyet az adott rendszer azonosítani képes. Probléma, ha egy rendszer szenzitivitása nagyon alacsony, tehát nem elég érzékeny, mert akkor nemcsak a helyzetértékelés sérül, hanem az elkülönítés, karantén intézkedések rendszere sem képes hatékonyan múködni. Még nagyobb baj, ha egy rendszer érzékenysége a járványügyi esemény közben még változik is, mert az torzíthatja a járványgörbét, extrém esetben akár ellenkező trendet is mutathat, mint a valóság. Ilyen problémát idézhet elő pl. az esetdefiníciók menet közben történő (néha elengedhetetlenül szükséges) változtatása, vagy a laboratóriumi megerósítés módszerének jelentôs változása (pl. laboratóriumi nukleinsavkimutatási vizsgálatok egy részének kiváltása antigénalapú gyorstesztekkel), illetve, ha a teszteredményeknek a bekerülése a surveillance-rendszerbe nem valósul meg teljeskörüen (mivel a gyorsteszteket jellemzően nem laboratóriumokban, hanem „betegágy mellett”, vagy egészségesek szürésére használják).

A pozitív prediktív érték ezzel szemben azt mutatja meg, hogy a surveillance-rendszerbe jelentett adatok mekkora hányada minősül valódi esetnek, és mekkora hányada álpozitív. Alacsony pozitív prediktív értékkel bíró surveillance-rendszerek múködtetése pazarló, mert a bejelentett álpozitív esetek felesleges járványügyi vizsgálatot, elkülönítést, karantént vonhatnak maguk után, feleslegesen akadályozva ezzel a gazdaság és a társadalom múködését.

A szenzitivitás és a pozitív prediktív érték alakulását fontos lenne ismerni a járványhullámok lezajlása során, fóleg, ha észlelünk olyan eseményt, amely jelentősen befolyásolhatja azt. A pontos értékek meghatározásának akadálya legtöbbször az, hogy viszonyítási alapként használható „arany standard” adatok, például egy olyan reprezentatív keresztmetszeti epidemiológiai vizsgálat, mint 
amilyen a H-UNCOVER volt, rendszeres időközönként megismételve, ritkán áll rendelkezésre (Merkely et al. 2020; URL 16).

Passzív surveillance-rendszerek esetén - mint amilyen a magyar COVID-19 esetbejelentő rendszer is - megengedőbben állunk a szenzitivitás kérdéséhez, mint aktív surveillance-ok esetén, mivel a COVID-19 klinikai megjelenése nagyon széles tüneti/klinikai spektrumon mozog. Az enyhe tünetekkel rendelkezők gyakran nem fordulnak orvoshoz, ezért aluldiagnosztizáltak, aluljelentettek. Ha az aluldetektálás aránya közel állandó szinten mozog a járványhullám során, akkor a járványgörbe lefutásának tendenciái továbbra is tükrözik a valós tendenciákat, csak alacsonyabb esetszámok szintjén. Ha azonban az aluldetektálás aránya menet közben is változik, akkor ez jelentősen torzíthatja a járványgörbe trendjeit, ami félrevezető lehet. Megfelelő szakértelemmel történő interpretálással azért ezen is lehet valamennyit segíteni.

Az aluldetektálás nagyságát nemcsak az orvoshoz fordulási szokások befolyásolják, hanem egyéb tényezők is, többek közt a diagnosztikus tesztek szenzitivitása, az egészségügyi ellátórendszer - és benne a tesztelések időbeli és térbeli hozzáférési egyenlőtlenségei, a tesztelési kapacitások személyi, tárgyi feltételei, valamint a jelentést nehezítő olyan tényező́k, mint például a hosszú, bonyolult ûrlapok, az elektronikus jelentési rendszer hiánya vagy fejletlensége, vagy az adatszolgáltató részéről felmerülő akadályozó tényezők (motiválatlanság, időhiány, képzés hiánya, túlterheltség). Az aluldetektálás, fóleg ha torzító hatású, és így a járványgörbe lefutását is téves útra viszi, az egyik legnagyobb kockázata a pontos helyzetértékelésnek és előrejelzésnek. Ezért az aluldetektálás mértékét javasolt monitorozni, és amennyire csak lehet, állandó szinten tartani.

\section{Külső paliditás}

Míg az alacsony szenzitivitás és pozitív prediktív érték legtöbbször alapvetően mennyiségi probléma, addig az esetleges alacsony külső validitás minőségi szempontból jelezhet problémát az adatokkal. Alapvetô elvárás a surveillance-rendszerekkel szemben, hogy a valós helyzetet mutassák be, mert a nem valid információ téves jelzéshez, téves döntéshez vezethet. A validitás ellenőrzésére egyrészt adatmenedzsment eszközök állnak rendelkezésre (pl. duplikátumok, inkonzisztens adatok kiszűrése, hiányzó vagy hibás adatok arányának monitorozása, adatjavítási mechanizmusok folyamatba építése), másrészt lehetőség van arra is, hogy a surveillance-adatokat validáljuk más releváns adatsorokkal (pl. Országos Mentőszolgálattól vagy az EESZT-ből származó adatokkal).

\section{Terbelhetöség}

Pandémia során a surveillance-rendszerek jelentős nyomás alá kerülnek, mivel a megszokott adatterhelés sokszorosát kell napi szinten kezelni. A járványügyben a gyorsaság kulcsfontosságú: minél régebbi helyzetet mutatnak be az adatok, annál nagyobb a döntési bizonytalanság. A surveillance-rendszerek túlterhelődése az észlelési időablakot növelheti. A monitorozásra többféle módszer is rendelkezésre áll (például a leletátfordulási idő vizsgálata, ami a minta laboratóriumba érkezésétól a validálást követő eredménykiadásig eltelt idő). A rendszerek túlterhelődésére készülni kell, annak észlelésekor pedig a szükséges erőforrás bevonását tervezett módon javasolt elvégezni.

A jelenlegi surveillance-rendszereink lassúsága a túl bonyolult adminisztratív folyamatokból, az átfedéseket mutató többféle adatgyújtésből, és a fejletlen informatikai háttérből adódik. A rendszereknek a járvány előrehaladtával együtt növekvő túlterhelődése azok további lassulásához és hibákhoz vezet. Gyorsabb, rugalmasabb és megbízhatóbb surveillance-rendszerekre van szükség annak érdekében, hogy a járványügyi felderítés eredményesebb legyen a jövőbeli pandémiás hullámok megelózése, leküzdése érdekében.

\section{Időbeliség}

A járványügyi surveillance-rendszerekből kinyert adatokon alapuló helyzetértékelésre nem úgy kell tekinteni, mint egy ablakra, amin keresztül az aktuális helyzetet látjuk, hanem sokkal inkább úgy, mint egy fényképre, ami egy múltbeli pillanatot mutat be. Például egy adott napon regisztrált megerősített COVID-19 esetnél a fertőzés több nappal az eset regisztrálása előtt történt. Az adott napi új megerősített COVID-19 esetszám ezért a terjedés szempontjából egy legalább 10-14 nappal korábbi járványügyi helyzetet tükröz. Ez a késlekedés részben a fertőzés természetéből adódik (1-14 napos inkubációs idő, orvoshoz fordulás késedelme enyhe tünetek esetén), részben az adminisztrációs és szervezési idők összességéből (tesztelésre várakozás, laborvizsgálat és leletkiadás ideje, bejelentés késedelme). Ugyanez a késés magyarázza azt is, hogy a központi korlátozó intézkedések hatása is csak legalább 2 hét késedelemmel mutatkozik meg a járványgörbén. A legalább kéthetes időablak a „vakrepülés” ideje, amit nem lehet nullára csökkenteni, azonban mindent el kell követni az adminisztratív és szervezési csúszások minimalizálása érdekében.

\section{Trendanalizisre és az $R$ becslésére való alkalmasság}

A pozitív tesztek arányának nyomon követése fontos mutató a napi megerősített COVID-19 esetszámok trendanalízisre való alkalmasságának megítélése szempontjából. Ha a valóságban nő a napi új esetszám, és a tesztelési aktivitást ezzel arányosan növeljük, akkor a pozitivitási arány változatlan marad. Ha azonban a valóságban nő a napi új esetszám, de a tesztelési aktivitás ezzel nem arányosan nő, hanem lemarad, akkor a detektálási arány fo- 
lyamatosan csökkenni, a pozitivitási arány növekedni fog. Ebben az esetben a naponta regisztrált új COVID-19 esetekre vonatkozó adatok egyre kevésbé lesznek képesek a valós trendeket mutatni, és a surveillance adatokból származó R-szám egyre kevésbé fogja a valós járványügyi helyzetet tükrözni. Ha a pozitivitási arány a járvány csúcsához közeledve egyre nő, akkor - épp a legkritikusabb időszakban - lesz a torzítás egyre jelentősebb a valósághoz képest. Ilyen esetekben érdemes olyan adatsorokat használni R-meghatározásra, melyek a tesztelési aktivitásnak kevésbé vannak kitéve - ilyen például a kórházi kezelést igénylő betegek napi száma -, mivel a súlyosabb lefolyású eseteknél a tesztelések a legnagyobb terhelés idején is nagy valószínúséggel megtörténnek.

\section{A szükséges mutatók képzésére alkalmas adatok gyüjtése}

Az epidemiológiai helyzetértékelésben megvan a maga helye az incidencia és a prevalencia típusú mutatóknak is, ha azokat arra használják és úgy interpretálják, amire valók. Mindkét mutató a jelenségek gyakoriságát méri egy adott populációban: az incidencia az új esetek előfordulását egy meghatározott időtartam alatt, a prevalencia a fennálló esetekét egy adott időpontban vagy időtartam alatt. Egy adott betegség prevalenciája nemcsak az új esetek számától függ, hanem a betegség időtartamától (lefolyásától), kezelésétől, prognózisától is. A prevalencia típusú mutatók elsôsorban a betegség aktuális terhét mutatják az adott populációban vagy az egészségügyi ellátórendszerben, ezért például kapacitástervezésre alkalmasak. Erre jó példa az EESZT rendszerében létrehozott adatgyưjiő ûrlap, amelyen keresztül minden fekvőbeteg-ellátásra hivatott, múködési engedéllyel rendelkező intézmény számára kötelező a napi adatszolgáltatás az egészségügyi ellátórendszer múködésének monitorozása céljából. Ebből az adatgyújtésből ismert többek között az adatközlés pillanatában fekvőbeteg-ellátásban részesülő, illetve súlyos állapotú és lélegeztetett, igazoltan COVID-19 betegek száma.

A járványfolyamat követésére azonban a prevalenciamutatók csak korlátozottan alkalmasak, inkább incidencia típusú adatokra lenne szükség, hogy ismerjük például azt, hogy az elmúlt 24 órában hány új igazolt COVID-19 beteg kezelését kezdték meg a kórházban, függetlenül attól, hogy a COVID-19 diagnózis már a felvételkor fennállt, vagy a laboratóriumi megerősítés egy már bent fekvő betegnél történt-e. Ennek az adatnak a hiányában csak a prevalencia típusú adatok használhatók fel a helyzetértékeléshez és előrejelzéshez, figyelembe véve annak korlátait. Javasolt a jövőben az adatgyüjtések tervezésekor gondolni arra, hogy a fekvőbeteg-ellátásban gyưjtött adatoknak nemcsak az egészségügyi ellátórendszer kapacitásának tervezéséhez, hanem az epidemiológiai helyzetértékeléshez szükséges információkat is tartalmazniuk kell, ezért az esetdefiníciók összehangolása elengedhetetlen.

\section{Hasznosság}

A surveillance-rendszernek megbízhatónak és hasznosnak kell lennie, azaz alkalmasnak arra, hogy célzott, hatásos intézkedéseket alapozzon meg. A járvány terjedésének megfékezése versenyfutás az idővel, az intézkedések idózítése ezért kulcsfontosságú. Ugyanakkora hatás eléréséhez kevésbé szigorú intézkedések is elegendőek, ha azokat korábban vezetik be. Minél magasabb esetszámoknál avatkoznak be, annál szigorúbb korlátozó intézkedéseket kell bevezetni, és a korlátozásokat annál hoszszabb ideig kell fenntartani annak érdekében, hogy a járvány újra kontroll alá kerüljön. Egy megfelelő surveillance-rendszer hasznosságát az adja, hogy már alacsony esetszámoknál is képes megbízható helyzetértékelést adni és pontos előrejelzést megalapozni az időben történő döntéshozatal támogatására.

\section{Rugalmasság, adaptációs képesség, új tipusú surveillance-rendszerek kialakitása}

A SARS-CoV-2 vírus mutációkra képes, és kifejlődhetnek olyan, különös aggodalomra okot adó új variánsok, amelyek egyrészt a gyorsabb terjedőképességük, másrészt - az elsóként az Egyesült Királyságban azonosított B.1.1.7 variáns esetén - a magasabb halálozási kockázatuk, harmadrészt a védőoltások hatásosságának csökkenése miatt igényelnek különös figyelmet (Iacobucci 2021: 372). Az új SARS-CoV-2 vírusvariánsok megjelenése és terjedése a jövőben is fordulatot hozhat a járványügyi helyzetben, és negatívan befolyásolhatja a védőoltási programok eredményességét. Fontos tehát, hogy pontos információval rendelkezzünk az új variánsokhoz köthető terjedési mintázatokról, hogy az időben történő helyi járványügyi intézkedésekkel az országos szintű elterjedésüket megelőzzük, megfékezzük. A célzott járványügyi intézkedések alapja az új variánsok elterjedtségének ismerete, amelyet egy megerősített laboratóriumi surveillance-rendszer képes biztosítani. Magyarországnak is szüksége volna az új variánsok szisztematikus monitorozását végző surveillance-rendszerre, melyet célszerü volna kompetens, erre a feladatra megfelelően felkészített laboratóriumok hálózatával megszervezni (URL 17), megcélozva az Európai Bizottság által javasolt mértékü - a SARS-CoV-2-vírus szempontjából pozitív minták legalább 5\%-ának megfelelő - genomszekvenálást (URL 18). Az átfogó monitoring rendszer kialakításához elengedhetetlen az egyéges szakmai protokoll, amely a genomszekvenáláson túl a mutációk célzott előszúrését, és az ezekből származó adatok koordinált gyưjtését, feldolgozását, elemzését és kommunikációját is szabályozza.

Számos országban alkalmaznak szindrómaalapú surveillance-rendszereket a járványügyi adatgyüjtés részeként, amelyek gyors és valósidejü kiegészítő adatokat szolgáltathatnak, tekintettel arra, hogy a rutinszerú egészségügyi ellátás során gyújtött, bizonyos tünetcsoportokra vonatkozó adatok (nem pedig specifikus tüne- 
tek vagy időigényes laboratóriumi megerősítés) alapján, „szélesebb merítéssel” múködnek. Egy újonnan megjelenő kórokozó esetén különös rugalmassággal bevethetők a szindrómaalapú adatgyújtések és kiegészítő korai jelzőrendszerként használhatók (Elliot et al. 2020: 148).

A világjárvány kezdete óta az ECDC egy egész Európára kiterjedő, összehangolt, súlyos heveny légúti megbetegedésekre (severe acute respiratory illness, SARI) vonatkozó kórházi surveillance-rendszer létrehozását szorgalmazza (URL 19). A SARI adatgyújtési rendszer számos európai országban már a világjárványt megelőzően múködött, ezért ezeken a helyeken gyorsan felhasználható volt a kórházi ellátást igénylő COVID-19 esetek időben történő azonosítására és klinikai jellemzőik gyors értékelésére. Magyarország sajnos még nem rendelkezik SARI-surveillance rendszerrel. Pedig a SARI-surveillance számos kérdésre adhatna választ akár még a COVID-19 betegség lefolyásával és kezelésével kapcsolatban is, különös tekintettel az új variánsok által okozott eltérő klinikai spektrumú megbetegedésekre, vagy a COVID-19 hosszú távú hatásainak vizsgálatára. Például Németországban a Robert Koch Intézet irányításával 2015 óta múködik az influenzaszerü megbetegedések kórházi surveillance-rendszere, amelynek 47 örszem kórház a tagja (Buda et al. 2017: 17). A pandémia korai szakaszában kisebb módosításokkal és összesen mintegy 70 kórház bevonásával gyorsan adaptálni tudták a rendszert a COVID-19 esetek monitorozására (Goerlitz et al. 2021: 64).

A szindrómaalapú surveillance-rendszerek az egészségügyi ellátás több szintjén is alkalmazhatók. Az angol közegészségügyi intézet (PHE) valósidejű surveillancerészlege például több adatbázisból származó, különböző tünetcsoportra vonatkozó, anonimizált egészségügyi adatok elemzésével követi nyomon a COVID-19 járványhelyzetet, elemzéseiket pedig heti rendszerességgel közzéteszik a honlapjukon. Többek között monitorozzák a légúti tünetek miatt a Nemzeti Egészségügyi Szolgálathoz (National Health Service, NHS) beérkezett telefonhívásokat, a háziorvoshoz fordulók és a mentőket hívók, valamint a sürgősségi ellátást igénylők számát is (URL 20).

\section{Hová kellene eljutni?}

Ahhoz, hogy a további járványhullámokat, vagy legalább az országos lezárásokat megelőzhessük, fejleszteni kell a készültséget, a járványügyi rendszereinket, és ezen belül is az észlelés, előrejelzés rendszerét. Az erre a célra allokált források minden bizonnyal bőven megtérülnének, mert így csökkenteni lehetne a gazdaság lezárásával sújtott napok számát.

Javaslatok az egészséget veszélyeztető járványügyi események észlelése, előrejelzése, a kockázatok értékelése és az informált döntéshozatal érdekében:

\section{$\rightarrow$ Rövid távon: további COVID-19 hullámok} megelózése

1. Újonnan felbukkanó, különös aggodalomra okot adó vírusvariánsok surveillance-rendszerének felállítása, genomszekvenálási képességek fejlesztése.

2. Hatékony és eredményes területi járványügyi munka. A COVID-19 esetek felderítése, laboratóriumi megerősítése ne csak diagnosztikus célból történjen, hanem a tesztelést stratégiai célból járványügyi helyzetértékelésre (surveillance), járványmegelőzésre, a járvány megfékezésére (esetek és kontaktok azonosítására, elkülönítésre és karantén intézkedésekre, vagy éppen annak kiváltására), járványgócok felszámolására is használják.

3. A jelenleg alkalmazott védőoltások hétköznapi körülmények közötti hatásosságának monitorozása megfelelő epidemiológiai módszertannal.

4. A kockázatkommunikáció és kríziskommunikáció fejlesztése, hiteles forrásokra, szakmai bizonyítékokra, tudományos konszenzusra támaszkodva. A lakosság kevésbé tájékozott speciális rétegeinek (idősebb korcsoportok, internetet nem használók, kedvezőtlen társadalmi-gazdasági helyzetűek stb.) célzott elérése a számukra hasznos járványügyi ismeretek (egyéni védekezés, oltások fontossága stb.) átadása céljából.

\section{$\rightarrow$ Hosszú távon: jövőbeli pandémiák megelőzése}

5. Átfogó pandémiás felkészülési terv készítése, mely kiterjed az egészségügyi szempontokon túl a társadalmi és gazdasági károk csökkentésére is.

6. A lakosság és az egészségügyi dolgozók rezilienciájának növelése a jövőbeli világjárványok káros következményeinek csökkentésére.

7. A járványügyi hálózat megújítása (minőségi és menynyiségi szempontok szerint egyaránt).

8. Magyar epidemiológusok képzése a legjobb külföldi egyetemeken és programokban, akik nemzetközi szintú tudományos együttmúködésekre és publikációs teljesítményre is képesek, és számukra perspektivikus hazai életpálya biztosítása.

9. Paradigmaváltás a járványügyben: a hagyományos, kizárólag egészségügyi végzettséggel rendelkező szakemberekből álló járványügyi elemzői és felderítői csoportban való gondolkodásról elmozdulás a multidiszciplináris, többféle kompetenciával rendelkező szakértői csoportok irányába.

10. Többszintû surveillance kialakítása: kis információtartalmú, gyors, általános adatszolgáltatási kötelezettséggel, valamint kijelölt, reprezentatív őrszemhelyek részletes, minőségi adatszolgáltatásával.

11. Innováció: új típusú surveillance-ok felállítása, új technológiákon alapuló módszerek (pl. okostelefonok által támogatott kontaktuskutatás, járványügyi vizsgálat stb.) bevetése a világjárványok előrejelzésére, megelőzésére és megfékezésére. 
12. Az egészségügyi informatikai rendszerek hasznosságának, minőségének, kapcsolatának és terhelhetőségének javítása. Felkészítésük alapvető, rutinszerú adatgyưjtésekre (interfészeken keresztül), elemzésre és automatikus jelzésadásra. Az alapadatokhoz képest mutatott szignifikáns eltérést az informatikai rendszerek emberi beavatkozás nélkül legyenek képesek megfelelő szakmai pontokon jelezni. Ily mó- don a szakemberek tehermentesíthetők volnának az adatgyưjések adminisztratív terhe alól, az adatokból értékelhető információk születnének a napi munkavégzés támogatására, és a szakemberek a jelzés értékelésére, validálására, kivizsgálására és a problémák megoldására fókuszálhatnának.

13. Magas színvonalú tudományos-kutatói háttér fenntartása (akkor is, amikor éppen nincs járvány).
- Ismert kockázatok esetén

Indikátor alapú surveillance

- kötelező fertőzőbeteg bejelentési rendszer

- hagyományos laboratóriumi surveillance

- új típusú genomikai („variáns”) surveillance

- Újonnan fellépő kockázatok esetén

- szindróma alapú surveillance

- halálozási monitoring

- egészségügyi ellátórendszer igénybevétel monitoring

- Nem humán-egészségügyi monitoring

- állategészségügyi surveillance

- környezeti monitoring

\section{Esemény alapú surveillance}

- Hazai esemény monitoring

-járványok kötelező jelentése

- kontaktuskutatás

- médiafigyelés

- készenléti jelentés

- telefonos zöld számon történő bejelentés stb.

- Nemzetközi esemény monitoring

- IHR (Nemzetközi Egészségügyi

Rendszabályok) és EWRS (korai riasztó és reagáló rendszer) fókuszpontok

- médiafigyelés

- nemzetközi szervezetek közleményei
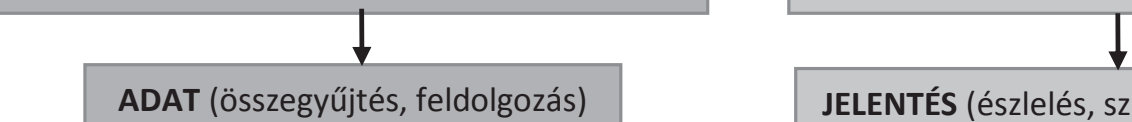

JELENTÉS (észlelés, szűrés, verifikálás)

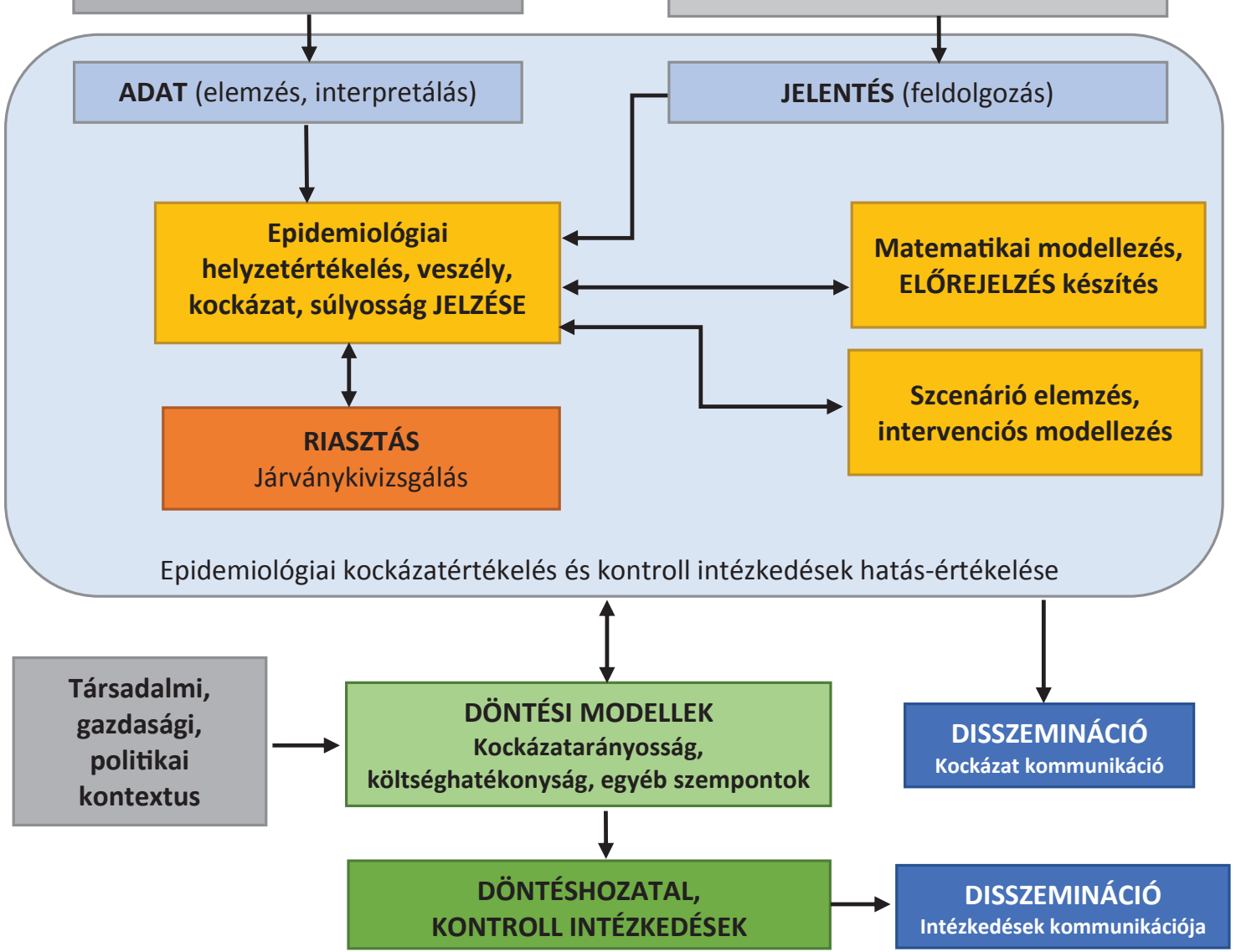

6. ábra

Elméleti keretrendszer az epidemiológiai felderítési rendszerhez (Epidemic Intelligence)

Forrás: ECDC (URL 21) és Shearer et al. 2020 alapján saját szerkesztés 
14. A surveillance-rendszer és járványmatematikai modellezés egységes keretrendszerben történő fejlesztése (6. ábra).

15. Az epidemiológiai felderítés információinak és előrejelzéseinek rendszerszintű becsatornázása a napi döntéshozatalba, és rendszeres visszacsatolások a döntéshozóktól (6. ábra).

\section{Következtetések}

A 2020 márciusa óta eltelt időszak alatt sikerült kialakítani egy olyan epidemiológiai helyzetértékelési és járványmatematikai modellezési rendszert, amely képes a különböző forrásokból származó adatokat és információkat egységes keretrendszerben feldolgozni, ezeket az információkat rendszerszerúen becsatornázni járványmatematikai szcenárió-elemzésekbe és előrejelzések készítésébe, valamint az előrejelzéseket a megvalósult járványügyi események tükrében értékelni.

Összességében elmondható, hogy a matematikai modellezés a 2. hullám minden fó aspektusát jól megragadta, és a veszélyes folyamatokat előre jelezte. Ezzel lehetőséget adott a gyorsreagálásra, ami azonban nem mindig valósult meg.

A COVID-19 pandémia egyik fontos tanulsága, hogy arányos, célzott és eredményes intézkedéseket csak a gyorsan változó járványügyi helyzet pontos ismeretének a birtokában lehet hozni. Ehhez pedig fejlett és átfogó surveillance-rendszerekre van szükség Magyarországon is. Az adat nem létezik magától, azt „el kell készíteni”, és minél nagyobb hozzáértéssel készítik el, annál jobb minőségü lesz, így az azon alapuló helyzetértékelések és előrejelzések annál pontosabb képet fognak visszatükrözni a valóságról.

A matematikai modellezés korábban nem volt része a járványügyi döntéshozatalnak Magyarországon, azonban számos nemzetközi példa és jó gyakorlat mutatta ennek létjogosultságát. A COVID-19 pandémia során korábban nem látott mértékben figyeltek mind a döntéshozók, mind a közvélemény a matematikai modellek eredményeire Magyarországon is. A pandémia másik fontos tanulsága, hogy hazánk is rendelkezik megfelelő tudományos szakmai háttérrel, amire a döntéshozók bizalommal támaszkodhatnak.

És itt jön a harmadik tanulság, és egyben javaslat, hogy a tudás és szakértelem rendelkezésre állása mellett arra is szükség van, hogy ezek olyan támogató rendszerbe kerüljenek, ahol a szükséges feltételek, valamint az adatokhoz és információkhoz való hozzáférés biztosított. Az ITM nemcsak létrehozta, hanem folyamatosan támogatta is a projekt múködését, biztosítva a szakemberek számára a megfelelő környezetet, valamint elősegítette a disszeminációt és az eredmények becsatornázását a döntéshozatalba.

$\mathrm{Az}$ epidemiológiai kockázatértékelés és matematikai modellezés, szcenárióelemzés rendszereit a továbbiakban is egységes keretrendszerben érdemes fejleszteni annak érdekében, hogy a matematikai modellek gyakorlatiasak, realisztikusak legyenek. Egyrészt a valós járványügyi helyzetből induljanak ki, másrészt az eredmények járványügyi szempontból is relevánsak legyenek, harmadrészt pedig az előrejelzések ellenórzése is megtörténjen a késóbbiekben a megvalósult forgatókönyv tényadatai alapján.

\section{Irodalomjegyzék}

Barbarossa, M. V., Bogya, N., Dénes, A., Röst, G., Varma, H. V., \& Vizi, Z. (2021) Fleeing lockdown and its impact on the size of epidemic outbreaks in the source and target regions - a COVID-19 lesson. Scientific Reports, Vol. 11. Article number: 9233 https:// doi.org/10.1038/s41598-021-88204-9

Bartha, F. A., Karsai, J., Tekeli, T., \& Röst, G. (2020) Symptom-based testing in a compartmental model of COVID-19. In: Analysis of Infectious Disease Problems (Covid-19) and Their Global Impact, Springer 2021

Boldog, P., Tekeli, T., Vizi, Z., Dénes, A., Bartha, F. A., \& Röst, G. (2020) Risk Assessment of Novel Coronavirus COVID-19 Outbreaks Outside China. Journal of Clinical Medicine, Vol. 9. No. 2. p. 571. https://doi.org/10.3390/jcm9020571

Bognár, B., Bódis L., Ferenci T., György L., Horváth J. K., Komlós K., Konyári E., Kovács N., Nagy A., Nagy Cs., Oláh D., Oroszi B., \& Röst G. (2020) Vállalati Fehér Könyv-gyakorlati útmutató a járványbelyzetre való felkészüléshez [Corporate White Book - Practical guide for the preparation and implementation of the corporate COVID-19 pandemic plan]. ITM Gazdaságstratégiáért és Szabályozásért Felelős Államtitkárság, Budapest, pp. 1-39. https://vali. ifka.hu/medias/919/20200901_vallalati_feher_konyv_kieg.pdf

Buda, S., Tolksdorf, K., Schuler, E., Kuhlen, R., \& Haas, W. (2017) Establishing an ICD-10 code based SARI-surveillance in Germany - description of the system and first results from five recent influenza seasons. BMC Public Health, Vol. 17. No. 1. p. 612. https:// doi.org/10.1186/s12889-017-4515-1

Elliot, A. J., Harcourt, S. E., Hughes, H. E., Loveridge, P., Morbey, R. A., Smith, S., Soriano, A., Bains, A., Smith, G. E., Edeghere, O., \& Oliver, I. (2020) The COVID-19 pandemic: a new challenge for syndromic surveillance. Epidemiology and infection, Vol. 148, e122. https://doi.org/10.1017/S0950268820001314

Davies, N. G., Abbott, S., Barnard, R. C., Jarvis, C. I., Kucharski, A. J., Munday, J. D., Pearson, C. A. B., Russell, T. W., Tully, D. C., Washburne, A. D., Wenseleers, T., Gimma, A., Waites, W., Wong, K. L. M., van Zandvoort, K., Silverman, J. D., CMMID COVID-19 Working Group, COVID-19 Genomics UK (COG-UK) Consortium, Diaz-Ordaz, K., Keogh, R., Eggo, R. M., Funk, S., Jit, M., Atkins, K. E., \& Edmunds, W. J. (2021) Estimated transmissibility and impact of SARS-CoV-2 lineage B.1.1.7 in England. Science, Vol. 372. No. 6538. eabg3055. DOI: 10.1126/science. abg3055. Epub 2021 Mar 3.

Goerlitz, L., Tolksdorf, K., Buchholz, U., Prahm, K., Preuß, U., An der Heiden, M., Wolff, T., Dürrwald, R., Nitsche, A., Michel, J., Haas, W., \& Buda, S. (2021) Überwachung von COVID-19 durch Erweiterung der etablierten Surveillance für Atemwegsinfektionen [Monitoring of COVID-19 by extending existing surveillance for acute respiratory infections]. Bundesgesundheitsblatt, Gesundheitsforschung, Gesundheitsschutz, Vol. 64. No. 4. 395-402. https:// doi.org/10.1007/s00103-021-03303-2

Iacobucci G. (2021) Covid-19: New UK variant may be linked to increased death rate, early data indicate. BMJ (Clinical research ed.), Vol. 372. No. 230. https://doi.org/10.1136/bmj.n230

Karsai, M., Koltai, J., Vásárhelyi, O., \& Röst, G. (2021) Hungary in Mask/MASZK in Hungary. Corvinus Journal of Sociology and Social Policy, Vol. 11. No. 2. pp. 139-146. 
Koltai, J., Vásárhelyi, O., Röst, G., \& Karsai, M. (2021) Monitoring behavioural responses during pandemic via reconstructed contact matrices from online and representative surveys. arXiv preprint arXiv:2102.09021.

Marzban, S., Han, R, Juhász, N., \& Röst, G. (2021) A hybrid PDE$A B M$ model for viral dynamics with application to SARS-CoV-2 and influenza. medRxiv preprint.

Merkely, B., Szabó, A. J., Kosztin, A., Berényi, E., Sebestyén, A., Lengyel, C., Merkely, G., Karády, J., Várkonyi, I., Papp, C., \& Miseta, A. (2020) Novel coronavirus epidemic in the Hungarian population, a cross-sectional nationwide survey to support the exit policy in Hungary. GeroScience, Vol. 42. No. 4. pp.1063-1074.

Péni, T., Csutak, B., Szederkényi, G., \& Röst, G. (2020) Nonlinear model predictive control with logic constraints for COVID-19 management. Nonlinear Dynamics, Vol. 102. No. 4. pp. 19651986. https://doi.org/10.1007/s11071-020-05980-1

Reguly, I., Csercsik, D., Juhász, J., Tornai, K., Bujtár, Zs., Horváth, G., Keömley-Horváth B., Kós, T., Cserey Gy., Iván, K., Pongor, S., Szederkényi, G., Röst, G., \& Csikász-Nagy, A. (2021) Microsimulation based evaluation of COVID-19 management strategies. preprint

Röst, G., Bartha, F. A., Bogya, N., Boldog, P., Dénes, A., Ferenci, T., Horváth, K. J., Juhász, A., Nagy, C., Tekeli, T., Vizi, Z., \& Oroszi, B. (2020) Early Phase of the COVID-19 Outbreak in Hungary and Post-Lockdown Scenarios. Viruses, Vol. 12. No. 7. p. 708. https:// doi.org/10.3390/v12070708

Shearer, F. M., Moss, R., McVernon, J., Ross, J. V., \& McCaw, J. M. (2020) Infectious disease pandemic planning and response: Incorporating decision analysis. PLoS Medicine, Vol. 17. No. 1. el003018. https://doi.org/10.1371/journal.pmed.1003018

Szócska, M. K., Pollner, P., Schiszler, I., Joo, T., Palicz, T., McKee, M., et al. (2021) Countrywide population movement monitoring using mobile devices generated (big) data during the COVID-19 crisis Scientific Reports, Vol. 11. Article number: 5943 (2021). https:// doi.org/10.1038/s41598-021-81873-6

Wallinga, J., \& Lipsitch, M. (2007) How generation intervals shape the relationship between growth rates and reproductive numbers Proceedings of the Royal Society B: Biological Sciences, Vol. 274. No. 1609. pp. 599-604.

\section{A cikkben található online hivatkozások}

URL 1: World Health Organization: WHO Coronavirus (COVID-19) Dashboard. https://covid19.who.int/

URL 2: Nemzeti Jogszabálytár. 1/2014. (I. 16.) EMMI rendelet a fertözö betegségek jelentésének rendjéröl. https://njt.hu/eli/v01/R/ 2014/EMMI/1

URL 3: World Health Organization. Public health surveillance for COVID-19: interim guidance. https://www.who.int/publications/i/item/who-2019-nCoV-surveillanceguidance-2020.8

URL 4: Eljárásrend a 2020. évben azonositott új koronavirussal kapcsolatban. https://www.nnk.gov.hu/index.php/koronavirus-tajekoztato/567-eljarasrend-a-2020-evben-azonositott-uj-koronavirussal-kapcsolatban

URL 5: Nemzeti Jogszabálytár. 18/1998. (VI. 3.) NM rendelet a fertözó betegségek és a járványok megelözése érdekében szühséges járványügyi intézkedésekröl. https://njt.hu/eli/v0l/R/1998/NM/18

URL 6: European Centre for Disease Prevention and Control. Guidelines for the implementation of nonpharmacentical interventions against COVID-19 in the EU/EEA and the UK. 24 September 2020. Stockholm; 2020. https://www.ecdc.europa.eu/sites/default/files/documents/covid-19-guidelines-non-pharmaceutical-interventions-september-2020.pdf

URL 7: Tájékoztató oldal a koronavírusról. Gulyás: meg kell akadályozni a vírus külföldröl történö behurcolását, 2020. július 12. https:// koronavirus.gov.hu/cikkek/gulyas-meg-kell-akadalyozni-viruskulfoldrol-torteno-behurcolasat

URL 8: Wolters Kluwer. 407/2020. (VIII. 30.) Korm. rendelet a batárellenôrzés ideiglenes visszaállitásáról. https://net.jogtar.hu/ jogszabaly?docid=A2000407.KOR\&dbnum $=1$

URL 9: Tájékoztató oldal a koronavirusról. Intézmény elhagyási és látogatási tilalom a szociális intézményekben, 2020. szeptember 8. https://koronavirus.gov.hu/cikkek/intezmeny-elhagyasi-es-latogatasi-tilalom-szocialis-intezmenyekben

URL 10: Wolters Kluwer. 431/2020. (IX. 18.) Korm. rendelet a járványügyi készültségi időszak védelmi intézkedéseiröl. https://net. jogtar.hu/jogszabaly?docid=a2000431. kor

URL 11: Tájékoztató oldal a koronavírusról. Országos tisztifóorvos: hétfötôl szigoritunk, mert szigoritani kell, 2020. november 01. https:// koronavirus.gov.hu/cikkek/orszagos-tisztifoorvos-hetfotol-szigoritunk-mert-szigoritani-kell

URL 12: Magyar Közlöny. 478/2020. (XI. 3.) Korm. rendelet a veszélyhelyzet kibirdetéséröl. https://magyarkozlony.hu/dokumentumok /8cbd29le418e353982f0af40c3a77d83c5d62fd4/megtekintes

URL 13: Wolters Kluwer. 484/2020. (XI. 10.) Korm. rendelet a veszélyhelyzet idején alkalmazandó védelmi intézkedések második ïtemérōl. https://net.jogtar.hu/jogszabaly?docid=a2000484. kor

URL 14: Tájékoztató oldal a koronavirusról. Országos tisztifóorvos: december 27-én kezdódik az egészségügyi dolgozók oltása 2020. december 23. https://koronavirus.gov.bu/cikkek/orszagos-tisztifoorvos-december-27-en-kezdodik-az-egeszsegugyi-dolgozok-oltasa

URL 15: Our World in Data: Coronavirus Source Data https://ourworldindata.org/coronavirus-source-data

URL 16: H-UNCOVER - Reprezentatín felmérés a koronavirus elleni küzdelemben - eredmények. https://www.ksh.hu/huncover_reprezentativ_felmeres_eredmenyek

URL 17: European Centre for Disease Prevention and Control: Guidance for representative and targeted genomic SARS-CoV-2 monitoring. https://www.ecdc.europa.eu/sites/default/files/documents/Guidance-for-representative-and-targeted-genomic-SARS-CoV-2-monitoring.pdf

URL 18: European Council and The Council. A United Front to Beat Covid-19. 2021.01. 19. COM(2021) 35 final. https://ec.europa. $\mathrm{eu} / \mathrm{info} /$ sites/info/files/communication-united-front-beatcovid-19_en.pdf? fbclid=IwARl UXnfFzlWs29fopDkX4RNQ mEj6T9allbhYgVj74fQZGl5Hqa2v7OVpkTk

URL 19: European Centre for Disease Prevention and Control: Strategies for the surveillance of COVID-19. https://www.ecdc.europa. $\mathrm{eu} /$ sites/default/files/documents/COVID-19-surveillance-strategy-9-Apr-2020.pdf

URL 20: Public Health England: Syndromic surveillance: weekly summaries for 2021. https://www.gov.uk/government/publications/ syndromic-surveillance-weekly-summaries-for-2021

URL 21: Surveillance of communicable diseases in the European Union - A long-term strategy: 2008-2013. https://www.ecdc.europa.eu/ en/publications-data/surveillance-communicable-diseases-european-union-long-term-strategy-2008-2013

A cikk a Creative Commons Attribution 4.0 International License (https://creativecommons.org/licenses/by/4.0/) feltételei szerint publikált Open Access közlemény, melynek szellemében a cikk bármilyen médiumban szabadon felhasználható, megosztható és újraközölhető, feltéve, hogy az eredeti szerző és a közlés helye, illetve a CC License linkje és az esetlegesen végrehajtott módosítások feltüntetésre kerülnek. (SID_1) 